\title{
Examining the effects of anthropogenic emissions on isoprene-derived secondary organic aerosol formation during the 2013 Southern Oxidant and Aerosol Study (SOAS) at the Look Rock, Tennessee ground site
}

\author{
S. H. Budisulistiorini ${ }^{1,6}$, X. Li ${ }^{1}$, S. T. Bairai ${ }^{2, a}$, J. Renfro ${ }^{3}$, Y. Liu ${ }^{4}$, Y. J. Liu ${ }^{4}$, K. A. McKinney ${ }^{4}$, S. T. Martin ${ }^{4}$, \\ V. F. McNeill ${ }^{5}$, H. O. T. Pye ${ }^{6}$, A. Nenes ${ }^{7,8,9}$, M. E. Neff ${ }^{10}$, E. A. Stone ${ }^{10}$, S. Mueller ${ }^{2, b}$, C. Knote ${ }^{11}$, S. L. Shaw ${ }^{12}$, \\ Z. Zhang ${ }^{1}$, A. Gold ${ }^{1}$, and J. D. Surratt ${ }^{1}$
}

${ }^{1}$ Department of Environmental Sciences and Engineering, Gillings School of Global Public Health, The University of North Carolina at Chapel Hill, Chapel Hill, NC, USA

${ }^{2}$ Tennessee Valley Authority, Muscle Shoals, AL, USA

${ }^{3}$ National Park Service, Gatlinburg, TN, USA

${ }^{4}$ School of Engineering and Applied Sciences, Harvard University, Cambridge, MA USA

${ }^{5}$ Department of Chemical Engineering, Columbia University, New York, USA

${ }^{6}$ National Exposure Research Laboratory, US Environmental Protection Agency, Research Triangle Park, NC, USA

${ }^{7}$ School of Earth and Atmospheric Sciences, Georgia Institute of Technology, Atlanta, GA, USA

${ }^{8}$ School of Chemical and Biomolecular Engineering, Georgia Institute of Technology, Atlanta, GA, USA

${ }^{9}$ ICE-HT, Foundation for Research and Technology, Hellas, Patras, Greece

${ }^{10}$ Department of Chemistry, University of Iowa, Iowa City, IA, USA

${ }^{11}$ Department of Experimental Meteorology, Ludwig Maximilian University of Munich, Munich, Germany

${ }^{12}$ Electric Power Research Institute, Palo Alto, CA, USA

${ }^{a}$ now at: Battelle, Pueblo, CO, USA

${ }^{b}$ now at: Ensafe, Nashville, TN, USA

Correspondence to: J. D. Surratt (surratt@unc.edu)

Received: 3 February 2015 - Published in Atmos. Chem. Phys. Discuss.: 10 March 2015

Revised: 15 July 2015 - Accepted: 29 July 2015 - Published: 13 August 2015

\begin{abstract}
A suite of offline and real-time gas- and particlephase measurements was deployed at Look Rock, Tennessee (TN), during the 2013 Southern Oxidant and Aerosol Study (SOAS) to examine the effects of anthropogenic emissions on isoprene-derived secondary organic aerosol (SOA) formation. High- and low-time-resolution $\mathrm{PM}_{2.5}$ samples were collected for analysis of known tracer compounds in isoprenederived SOA by gas chromatography/electron ionizationmass spectrometry (GC/EI-MS) and ultra performance liquid chromatography/diode array detection-electrospray ionization-high-resolution quadrupole time-of-flight mass spectrometry (UPLC/DAD-ESI-HR-QTOFMS). Source apportionment of the organic aerosol (OA) was determined by positive matrix factorization (PMF) analysis of mass spectro-
\end{abstract}

metric data acquired on an Aerodyne Aerosol Chemical Speciation Monitor (ACSM). Campaign average mass concentrations of the sum of quantified isoprene-derived SOA tracers contributed to $\sim 9 \%$ (up to $28 \%$ ) of the total OA mass, with isoprene-epoxydiol (IEPOX) chemistry accounting for $\sim 97 \%$ of the quantified tracers. PMF analysis resolved a factor with a profile similar to the IEPOX-OA factor resolved in an Atlanta study and was therefore designated IEPOXOA. This factor was strongly correlated $\left(r^{2}>0.7\right)$ with 2 methyltetrols, $\mathrm{C}_{5}$-alkene triols, IEPOX-derived organosulfates, and dimers of organosulfates, confirming the role of IEPOX chemistry as the source. On average, IEPOX-derived SOA tracer mass was $\sim 26 \%$ (up to $49 \%$ ) of the IEPOXOA factor mass, which accounted for $32 \%$ of the total 
OA. A low-volatility oxygenated organic aerosol (LV-OOA) and an oxidized factor with a profile similar to $91 \mathrm{Fac}$ observed in areas where emissions are biogenic-dominated were also resolved by PMF analysis, whereas no primary organic aerosol (POA) sources could be resolved. These findings were consistent with low levels of primary pollutants, such as nitric oxide (NO $\sim 0.03 \mathrm{ppb}$ ), carbon monoxide $\left(\mathrm{CO} \sim 116 \mathrm{ppb}\right.$ ), and black carbon $\left(\mathrm{BC} \sim 0.2 \mu \mathrm{g} \mathrm{m}^{-3}\right)$. Particle-phase sulfate is fairly correlated $\left(r^{2} \sim 0.3\right)$ with both methacrylic acid epoxide (MAE)/hydroxymethyl-methyl- $\alpha$ lactone (HMML)- (henceforth called methacrolein (MACR)derived SOA tracers) and IEPOX-derived SOA tracers, and more strongly correlated $\left(r^{2} \sim 0.6\right)$ with the IEPOX-OA factor, in sum suggesting an important role of sulfate in isoprene SOA formation. Moderate correlation between the MACRderived SOA tracer 2-methylglyceric acid with sum of reactive and reservoir nitrogen oxides $\left(\mathrm{NO}_{y} ; r^{2}=0.38\right)$ and nitrate $\left(r^{2}=0.45\right)$ indicates the potential influence of anthropogenic emissions through long-range transport. Despite the lack of a clear association of IEPOX-OA with locally estimated aerosol acidity and liquid water content (LWC), box model calculations of IEPOX uptake using the simpleGAMMA model, accounting for the role of acidity and aerosol water, predicted the abundance of the IEPOX-derived SOA tracers 2-methyltetrols and the corresponding sulfates with good accuracy $\left(r^{2} \sim 0.5\right.$ and $\sim 0.7$, respectively). The modeling and data combined suggest an anthropogenic influence on isoprene-derived SOA formation through acidcatalyzed heterogeneous chemistry of IEPOX in the southeastern US. However, it appears that this process was not limited by aerosol acidity or LWC at Look Rock during SOAS. Future studies should further explore the extent to which acidity and LWC as well as aerosol viscosity and morphology becomes a limiting factor of IEPOX-derived SOA, and their modulation by anthropogenic emissions.

\section{Introduction}

Atmospheric fine particulate matter $\left(\mathrm{PM}_{2.5}\right.$, aerosol with aerodynamic diameter $\leq 2.5 \mu \mathrm{m}$ ) can scatter and/or absorb solar and terrestrial radiation as well as influence cloud formation and as a result, can markedly affect regional and global climate (IPCC, 2013). It is now also established that exposure to $\mathrm{PM}_{2.5}$ can have an adverse impact on human health (Dockery et al., 1993; Mauderly and Chow, 2008; Hsu et al., 2011). Organic matter (OM) comprises the largest mass fraction of $\mathrm{PM}_{2.5}$ and is derived largely from secondary organic aerosol (SOA) formed through atmospheric oxidation of volatile organic compounds (VOCs). SOA formation has been modeled primarily within the framework of absorptive gas-to-particle partitioning (Pankow, 1994; Odum et al., 1996), with the products of volatile and semi-volatile organic precursors decreasing in volatility during multi- generational oxidation, and condensing onto pre-existing particles or creating new particles through nucleation. Recent work has demonstrated the importance of heterogeneous (or particle-phase) chemistry in SOA formation (Jang et al., 2002; Kalberer et al., 2004; Tolocka et al., 2004; Gao et al., 2004; Surratt et al., 2006); however, chemical transport models are only just beginning to incorporate explicit details of this chemistry for specific SOA precursors (Pye et al., 2013; Karambelas et al., 2014). Although much progress has been made in recent years in identifying key biogenic and anthropogenic SOA precursors, significant gaps still remain in our knowledge of the formation mechanisms, composition and properties of SOA (Hallquist et al., 2009).

Isoprene (2-methyl-1,3-butadiene, $\mathrm{C}_{5} \mathrm{H}_{8}$ ) is the most abundant non-methane VOC emitted into Earth's atmosphere at $\sim 600 \mathrm{Tg} \mathrm{yr}^{-1}$ (Guenther et al., 2006). The southeastern US during summer is a particularly strong source of isoprene, primarily through emissions by broad-leaf trees. Although isoprene is known to influence urban ozone $\left(\mathrm{O}_{3}\right)$ formation in the southeastern US, only in the last decade has hydroxyl radical $(\mathrm{OH})$-initiated oxidation been recognized as leading to significant SOA formation, enhanced by the presence of anthropogenic pollutants such as nitrogen oxides $\left(\mathrm{NO}_{x}=\mathrm{NO}+\mathrm{NO}_{2}\right)$ and sulfur dioxide $\left(\mathrm{SO}_{2}\right)$ (Claeys et al., 2004; Edney et al., 2005; Surratt et al., 2006, 2010; Kroll et al., 2006). Previously, the volatility of the photochemical oxidation products had been assumed to preclude formation of $\mathrm{PM}_{2.5}$ from isoprene oxidation (Pandis et al., 1991; Kamens et al., 1982).

Recent studies have made significant strides in identifying critical intermediates in isoprene SOA formation by varying the levels of $\mathrm{NO}_{x}$ (Kroll et al., 2006; Surratt et al., 2006, 2010) and acidity of sulfate aerosol (Surratt et al., 2006; Surratt et al., 2010; Lin et al., 2012, 2013a). The proposed role of isomeric isoprene epoxydiols (IEPOX) as key intermediates in the formation of isoprene SOA under low-nitric oxide (NO) conditions (Surratt et al., 2010; Paulot et al., 2009) has recently been confirmed in studies using authentic compounds (Lin et al., 2012; Gaston et al., 2014; Nguyen et al., 2014). Under high-NO conditions, isoprene SOA has been demonstrated to form primarily via oxidation of methacrolein (MACR) (Surratt et al., 2006) and methacryloylperoxynitrate (MPAN) (Surratt et al., 2010) with methacrylic acid epoxide (MAE) (Lin et al., 2013b) and hydroxymethyl-methyl- $\alpha$-lactone (HMML) (Nguyen et al., 2015) from the further oxidation of MPAN demonstrated as reactive intermediates. Under both high- and low-NO conditions, acid-catalyzed reactive uptake and multiphase chemistry of isoprene-derived epoxides (IEPOX and MAE) as well as aqueous reactions of MACR and methyl vinyl ketone (MVK) with sulfate radical anion are now known to enhance SOA formation from isoprene (Surratt et al., 2007b, 2010; Lin et al., 2013b; Schindelka et al., 2013). Recent flowtube studies on reactive uptake kinetics of trans- $\beta$-IEPOX (Gaston et al., 2014), the predominant IEPOX isomer formed 
in the photochemical oxidation of isoprene (Bates et al., 2014), have estimated an atmospheric lifetime shorter than $5 \mathrm{~h}$ in the presence of highly acidic aqueous aerosol $(\mathrm{pH} \leq 1)$. Since the predicted atmospheric lifetime of IEPOX for gasphase oxidation is $8-33 \mathrm{~h}$ at an average $\mathrm{OH}$ concentration of $10^{6}$ molecules $\mathrm{cm}^{-3}$ (Jacobs et al., 2013; Bates et al., 2014) and $11 \mathrm{~h}$ for deposition (Eddingsaas et al., 2010), reactive uptake of IEPOX onto highly acidic aqueous aerosol would be a competitive or potentially dominant fate of IEPOX in the atmosphere. Recent field data from sites across the southeastern US collected by Guo et al. (2015) yielded estimates that aerosol $\mathrm{pH}$ ranges from $0.5-2$. Consistent with expectations based on the flow-tube studies (Gaston et al., 2014; Riedel et al., 2015) and $\mathrm{pH}$ estimates from field data, IEPOXderived SOA has been observed to account for up to $33 \%$ of the total fine organic aerosol (OA) mass collected during summer in downtown Atlanta, GA, by analysis of data acquired on an online Aerodyne Aerosol Chemical Speciation Monitor (ACSM) (Budisulistiorini et al., 2013). Similar level of isoprene-derived SOA has been recently observed at other field sites across the southeastern US using the Aerodyne high-resolution time-of-flight aerosol mass spectrometer (HR-ToF-AMS) (Xu et al., 2015). In offline chemical analysis of total fine OA mass at a rural site located in Yorkville, GA (Lin et al., 2013b), up to $20 \%$ of the OA mass could be attributed to the known IEPOX-derived SOA tracers, including the 2-methyltetrols (Claeys et al., 2004; Lin et al., 2012), $\mathrm{C}_{5}$-alkene triols (Wang et al., 2005; Lin et al., 2012), cis- and trans-3-methyltetrahydrofuran-3,4-diols (Lin et al., 2012; Zhang et al., 2012b) and IEPOX-derived organosulfates (Surratt et al., 2007a, 2010; Lin et al., 2012).

In addition to examining the effects of $\mathrm{NO}$ and aerosol acidity on isoprene SOA formation, the effect of varying relative humidity $(\mathrm{RH})$ has recently been examined. In chamber studies on the high-NO pathway under low-RH conditions, the isoprene SOA constituents 2-methylglyceric acid and corresponding oligoesters derived from MACR and its associated SOA precursors (i.e., HMML and MAE) were influenced by RH conditions (Zhang et al., 2011; Nguyen et al., 2011, 2015). However, 2-methyltetrols, which are known to be major SOA constituents formed in the low-NO pathway and minor constituents in the high-NO pathway (Edney et al., 2005; Surratt et al., 2007b), did not vary significantly with RH (Zhang et al., 2011). While RH appears to have an effect on the formation of certain isoprene SOA constituents, recent flow-tube studies demonstrated that aerosol acidity has a more pronounced effect on IEPOX- and MAEderived SOA formation than RH (Gaston et al., 2014; Riedel et al., 2015). However, field studies have yielded mixed results. At Yorkville, GA, Lin et al. (2013a) observed no strong correlation of IEPOX-derived SOA with aerosol acidity, $\mathrm{NH}_{3}$ levels or liquid water content (LWC), although there was a statistically significant enhancement of IEPOX-derived SOA under high $\mathrm{SO}_{2}$-sampling scenarios. Similarly, no correlation between isoprene SOA tracers and aerosol $\mathrm{pH}$ or LWC was observed in the analysis of filter samples collected from field studies in Sacramento, CA, and Carson City, NV (Worton et al., 2013), and in the isoprene-derived PMF factor from field study in Centerville, AL (Xu et al., 2015). Another recent field study by Budisulistiorini et al. (2013) found weak correlation $\left(r^{2}=0.22\right)$ between aerosol $\mathrm{pH}$ and an IEPOX-OA factor resolved by positive matrix factorization (PMF) from real-time organic aerosol mass spectra data acquired on an Aerodyne ACSM.

Although isoprene is now recognized as a major source of SOA, the exact manner in which isoprene-derived SOA is formed in the southeastern US and how it is affected by anthropogenic pollutants (i.e., $\mathrm{NO}_{x}$ level, aerosol acidity, sulfate and primary aerosol loadings) remains unclear. The gap in understanding has major public health and policy implications since isoprene is emitted primarily from terrestrial vegetation and is not controllable; whereas strategies to control anthropogenic pollutants can be implemented. Improving our fundamental understanding of the role of anthropogenic emissions in isoprene SOA formation will be key in improving existing air quality models, especially in the southeastern US where models currently under-predict isoprene SOA formation (Foley et al., 2010; Carlton et al., 2010) and as a result will be critical to developing efficient control strategies for improving air quality. The study presented here is part of the 2013 Southeast Oxidant and Aerosol Study (SOAS) spanning 1 June to 17 July 2013 at the Look Rock (LRK), TN ground site (maps are provided in the Supplement). A major aim of SOAS was to address the issue of how exactly isoprene SOA formation occurs and the potential of anthropogenic emissions to enhance SOA formation. At the LRK ground site we approached this aim by examining the chemical composition of OA measured in real-time by the Aerodyne ACSM and subsequently applying PMF for source apportionment. We also collected $\mathrm{PM}_{2.5}$ on filters and quantified tracers associated with isoprene chemistry to support the assignment of OA factors resolved from factor analyses of organic mass spectral data collected by the ACSM. We examined the potential influence of anthropogenic emissions on isoprene-derived SOA by correlation with temporal variation of anthropogenic markers monitored by collocated instruments. Finally, a photochemical box model was employed to further examine the potential interactions between SOA and anthropogenic emissions. The results of this study will help to improve model parameterizations required to bring model predictions closer to ambient observations of isoprene-derived SOA formation in the southeastern US.

\section{Methods}

\subsection{Site description}

Fine aerosol was collected continuously from 1 June to 17 July 2013. LRK is a ridge-top site located on the north- 
western edge of the Great Smoky Mountains National Park (GSMNP) downwind of Maryville and Knoxville and small farms with animal grazing areas (Supplement Figs. S1-S2). Up-slope flow carries pollutants emitted in the valley during early morning to the LRK site by mid-morning (Tanner et al., 2005). In the evening, down-slope flow accompanies a shift of wind direction to the south and east during summer that isolates the site from fresh primary emissions from the valley and allows aged-secondary species to accumulate (Tanner et al., 2005). As described in Tanner et al. (2005), particulate sulfate, black carbon (BC), organic carbon (OC), $\mathrm{PM}_{2.5}$ and $\mathrm{PM}_{10}$ as well as gas-phase sulfur dioxide $\left(\mathrm{SO}_{2}\right)$, nitric oxide (NO), nitrogen dioxide $\left(\mathrm{NO}_{2}\right)$, and sum of reactive and reservoir nitrogen oxides $\left(\mathrm{NO}_{y}\right)$ were measured by a suite of collocated instruments throughout the campaign (Table S1 in the Supplement). Meteorological measurements (RH, temperature, wind direction, and wind speed) and $\mathrm{O}_{3}$ concentrations were acquired at a National Park Service (NPS) shelter across a secondary road opposite the LRK shelter.

\subsection{ACSM NR-PM 1 characterization}

Fine ambient aerosol was sampled from the rooftop of the LRK site air-conditioned building during the SOAS campaign. The sampling inlet was approximately $6 \mathrm{~m}$ above the ground and equipped with a $\mathrm{PM}_{2.5}$ cyclone. Sample was drawn at $3 \mathrm{~L} \mathrm{~min}^{-1}$ (residence time $<2 \mathrm{~s}$ ) and dried using a Nafion drier (PD-200T-24SS, Perma Pure) to maintain RH below $10 \%$ and prevent condensation during sampling. ACSM operation parameters followed those of previous studies (Budisulistiorini et al., 2013, 2014). Briefly, the ACSM scanning rate was set at $200 \mathrm{~ms} \mathrm{amu}^{-1}$ and data were averaged over 30 min intervals. Data were acquired using ACSM DAQ version 1438 and analyzed using ACSM Local version 1532 (Aerodyne Research, Inc.) within Igor Pro 6.3 (WaveMetrics). Calibrations for sampling flow rate, mass-to-charge ratio $(m / z)$, response factor of nitrate $\left(\mathrm{RF}_{\mathrm{NO}_{3}}\right)$, and relative ionization efficiencies of both ammonium $\left(\mathrm{RIE}_{\mathrm{NH}_{4}}\right)$ and sulfate $\left(\mathrm{RIE}_{\mathrm{SO}_{4}}\right)$ were performed three times during the campaign. Mass resolution, heater bias and ionizer voltages, and amplifier zero settings were checked and adjusted daily. A collection efficiency (CE) of 0.5 calculated based on Middlebrook et al. (2012) was applied to the ACSM data in order to accommodate composition-dependent CE. Correlations of combined aerosol mass concentrations of ACSM non-refractory (NR)-PM $\mathrm{PM}_{1}$ and collocated black carbon (BC) with aerosol volume concentrations of $\mathrm{PM}_{1}$ measured by the Scanning Electrical Mobility Spectrometer/Mixing Condensation Particle Counter (SEMS-MCPC, Brechtel Manufacturing Inc.) was strong $\left(r^{2}=0.89\right)$ and suggested an aerosol density of $1.52 \mathrm{~g} \mathrm{~cm}^{-3}$ (Fig. S3), close to that reported in previous studies in Pasadena, CA (Hayes et al., 2013) and Atlanta, GA (Budisulistiorini et al., 2014). If CE of 1 is used, the estimated aerosol density is $0.78 \mathrm{~g} \mathrm{~cm}^{-3}$, which is much lower than suggested bulk organic and inorganic aerosol den- sities of 1.27 and $1.77 \mathrm{~g} \mathrm{~cm}^{-3}$, respectively (Cross et al., 2007).

\subsection{OA source characterization}

OA fraction acquired by the ACSM was analyzed using PMF (Paatero and Tapper, 1994) written in PMF Evaluation Tool (PET v2.4) (Ulbrich et al., 2009). In this study, uncertainty of a selected solution was investigated with Seeds (varied from 0 to 100, in steps of 5), 100 bootstrapping runs, and Fpeak parameters. Details of diagnostics for each PMF analysis are given in the Supplement (Tables S2-S3 and Figs. S4-S8). Evaluation of $Q / Q_{\exp }$ time series and mass spectra and correlation of factor solutions at Fpeak 0 with collocated measurements (Figs. S4-S5, Table S3) suggests that a 3-factor solution is optimum. We selected a 3-factor solution at Fpeak -0.09 based on the quality of PMF fits and interpretability when compared to tracer time series and reference mass spectra (Table S5). The mass spectrum of a factor designated IEPOX-OA conforms closely to the IEPOX-SOA factor resolved in Atlanta, GA (Budisulistiorini et al., 2013). The mass spectrum of the second factor correlates closely with the factor identified as LV-OOA in previous studies (Ulbrich et al., 2009; $\mathrm{Ng}$ et al., 2011). The third factor is designated 91Fac, based on the similarity of its mass spectrum to the factor $91 \mathrm{Fac}$, an oxygenated factor resolved in areas dominated by biogenic emissions (Robinson et al., 2011; Chen et al., 2015).

\subsection{Gas-phase measurements}

\subsubsection{High-resolution time-of-flight chemical ionization mass spectrometry (HR-ToF-CIMS) measurements}

Gaseous samples were measured through an approximately $1 \mathrm{~m}$ length of polytetrafluoroethylene (PTFE) tubing $\left(1 / 4^{\prime \prime}\right.$ outside diameter) from the sidewall of the building at flow rate of $2 \mathrm{~L} \mathrm{~min}^{-1}$. The sampling line was placed to face the valley such that no structures or activity would compromise sampling. Instrument performance was maintained daily by baseline, threshold, and single ion area tuning as well as $\mathrm{m} / \mathrm{z}$ calibration. The instrument was not operational during some periods of the field campaign (i.e., 13 to 16 June, 21 June to 4 July, and 14 to 16 July) due to power outage, broken components, and necessary maintenances. July HR-ToF-CIMS data were corrected by comparing them to collocated MVK+MACR data measured by PTR-TOF-MS (proton-transfer-reaction time-of-flight mass spectrometer) (Sect. 2.4.2) and post-campaign calibration in order to derive a correction factor to account for decay in the micro-channel plate (MCP) detector.

The HR-ToF-CIMS instrument was operated in the negative ion mode using acetate ion chemistry for detection of isoprene-derived epoxides. It is henceforth referred as ac- 
etate CIMS. The acetate ion system efficiently detects small organic acids via deprotonation (Veres et al., 2008; Bertram et al., 2011), such as MAE, and some vicinal diol species, such as the IEPOX, as clusters with the reagent ion. MAE is detected as the $\left[\mathrm{C}_{4} \mathrm{H}_{5} \mathrm{O}_{3}\right]^{-}$ion at $m / z$ 101, whereas IEPOX is detected as the $\left[\mathrm{CH}_{3} \mathrm{COO}+\mathrm{C}_{5} \mathrm{H}_{10} \mathrm{O}_{3}\right]^{-}$ion at $m / z 177$ (Fig. S9). IEPOX and its gas-phase precursor, hydroxyhydroperoxides (ISOPOOH), were previously measured by CIMS with triple-quadrupole mass spectrometer that provides tandem mass spectra, as cluster ion with $\mathrm{CF}_{3} \mathrm{O}^{-}$at similar $m / z$ and were distinguishable through their daughter ions using collision-induced dissociation (Paulot et al., 2009). Recent field and laboratory studies using acetate CIMS found that both ISOPOOH and IEPOX were observed at the same cluster ion at $m / z$ 177. In our measurements, interferences of ISOPOOH to the cluster ion $\mathrm{m} / z 177$ could not be differentiated because we could only observe the parent ions unlike Paulot et al. (2009). Our acetate CIMS sensitivities were measured to be relatively similar towards IEPOX and ISOPOOH at $10^{-7}$ and $9.9 \times 10^{-8}$ signal $\mathrm{ppt}^{-1}$, respectively. However, since we operated the acetate CIMS at different voltage settings than from D. K. Farmer, personal communication (2015), sensitivity of the deprotonated form of IEPOX is very low, and thus it could not be used to quantitatively measure IEPOX and/or to define the fractional contribution of IEPOX and ISOPOOH to the $m / z 177$ signal. We synthesized ISOPOOH (see Fig. S10 for nuclear magnetic resonance (NMR) data) and measured CIMS sensitivities toward ISOPOOH and IEPOX. Results indicated that response factors of both compounds were similar (see Fig. S11). Investigation of lowering the IEPOX mixing ratio by a constant factor of total $m / z 177$ signal, which will be reported in a future study, showed that SOA tracer model correlations are not sensitive to this and only tracers mass loadings vary with the IEPOX:ISOPOOH ratio. The inability to distinguish IEPOX from ISOPOOH is a limitation in our study. Therefore, we carefully note here that the $m / z 177$ ion measured during this study represents the upper limit of the IEPOX mixing ratio due to ISOPOOH interference at an unknown fraction of the signal.

Gaseous IEPOX and MAE were quantified with acetate CIMS by applying laboratory-derived calibration factors. All signals were normalized to acetate ion $\left[\mathrm{CH}_{3} \mathrm{COO}\right]^{-}$at $\mathrm{m} / z$ 59 to take into account fluctuations in signal arising from changes in pressure during the course of field sampling and calibration. Calibrations were performed before and after the SOAS campaign using synthetic trans- $\beta$-IEPOX and MAE standards through dilution in a dark $10 \mathrm{~m}^{3}$ indoor chamber at the University of North Carolina (UNC) (Lin et al., 2012). Synthetic procedures for trans- $\beta$-IEPOX and MAE have been described previously (Zhang et al., 2012b; Lin et al., 2013b). A known concentration of epoxide standard was injected into a $10 \mathrm{~mL}$ glass manifold using glass microliter syringes. The manifold was wrapped with heating tape and flushed with heated $\mathrm{N}_{2}(\mathrm{~g})$ at $5 \mathrm{~L} \mathrm{~min}^{-1}$ for at least
$2 \mathrm{~h}$ to the indoor chamber being sampled by the HR-ToFCIMS until ion signals associated with MAE and IEPOX stabilized. We assumed unit injection efficiency of the epoxides through the glass chamber and into the chamber in calculating the chamber epoxide mixing ratios. Subsequently, we performed standard dilution of the acetate CIMS sample flow by using a $T$ piece in an $\mathrm{N}_{2}$ (g) flow controlled by eight different micro-orifices to obtain an eight-point calibration curve. During the course of the calibration experiments, we accounted for the fact that we would lose 14 and $3 \%$ of IEPOX and MAE, respectively. Wall loss rates for IEPOX and MAE have been measured in the chamber and are $5.91 \times 10^{-5} \mathrm{~s}^{-1}$ and $1.12 \times 10^{-5} \mathrm{~s}^{-1}$, respectively (Riedel et al., 2015). The chamber was sampled continuously at $2 \mathrm{~L} \mathrm{~min}^{-1}$ for measurement of gaseous products by acetate CIMS and at $0.36 \mathrm{Lmin}^{-1}$ for aerosol measurements by SEMS-MCPC to ensure that the chamber was particle free. Additionally, no particle nucleation events or significant particle loadings were observed over the course of calibrations. Normalized $\mathrm{m} / \mathrm{z} 177$ and 101 ions were plotted against epoxide mixing ratios of eight-point standards; however, only four-point standards were used for IEPOX calibration due to non-linearity. Slopes of the fittings were used as calibration factors for the field measurements (Fig. S12). Field calibrations were not performed due to the unavailability of IEPOX and MAE permeation tube systems.

\subsubsection{Proton transfer reaction time-of-flight mass spectrometry (PTR-TOF-MS)}

A proton-transfer-reaction time-of-flight mass spectrometer (PTR-TOF-MS 8000, Ionicon Analytik GmbH, Austria) equipped with switchable reagent ion capacity was used to measure the concentrations of gaseous organic species at the site. Ambient air was sampled from an inlet mounted on a tower ca. $2 \mathrm{~m}$ above the rooftop of the LRK site building through a $6.35 \mathrm{~mm}$ OD perfluoroakoxy (PFA) sampling line at $4-5$ standard $\mathrm{L} \mathrm{min}^{-1}$. A $2.0 \mu \mathrm{m}$ pore size $47 \mathrm{~mm}$ diameter Zefluor teflon filter (Pall Corporation) at the inlet removed particles from the sample flow. The PTR-TOF-MS subsampled from this flow at a rate of 0.25 standard $\mathrm{L} \mathrm{min}^{-1}$, resulting in a total inlet transit time of ca. 1-2 s.

PTR-TOF-MS has been described previously by Jordan et al. (2009a, b) and Graus et al. (2010) and was operated in this study as described in Liu et al. (2013). $\mathrm{H}_{3} \mathrm{O}^{+}$reagent ions were used to selectively ionize organic molecules in the sample air. A high-resolution TOF detector (Tofwerk AG, Switzerland) was used to analyze the reagent and product ions and allowed for exact identification of the ion molecular formula (mass resolution $>4000$ ). The instrument was operated with a drift tube temperature of $80^{\circ} \mathrm{C}$ and a drift tube pressure of 2.35 mbar. In $\mathrm{H}_{3} \mathrm{O}^{+}$mode, the drift tube voltage was set to $520 \mathrm{~V}$, resulting in an $\mathrm{E} / \mathrm{N}$ of $120 \mathrm{Td}(E$, electric field strength; $N$, number density of air in the drift tube; unit, Townsend, Td; $1 \mathrm{Td}=10^{-17} \mathrm{~V} \mathrm{~cm}^{2}$ ). PTR-TOF-MS spectra 
were collected at a time resolution of $10 \mathrm{~s}$. Mass calibration was performed every $2 \mathrm{~min}$ with data acquisition using the Tof-Daq v1.91 software (Tofwerk AG, Switzerland).

A calibration system was used to establish the instrument sensitivities to VOCs. Gas standards (Scott Specialty Gases) were added into a humidified zero air flow at controlled flow rates. Every $3 \mathrm{~h}$ the inlet flow was switched to pass through a catalytic converter (platinum on glass wool heated to $350^{\circ} \mathrm{C}$ ) to remove VOCs and establish background intensities.

\subsection{Filter sampling methods and offline chemical analyses}

$\mathrm{PM}_{2.5}$ samples were collected on pre-baked Tissuquartz ${ }^{\mathrm{TM}}$ Filters (Pall Life Sciences, $8 \times 10$ in) with three highvolume $\mathrm{PM}_{2.5}$ samplers (Tisch Environmental, Inc.). All high-volume $\mathrm{PM}_{2.5}$ samplers were equipped with cyclones operated at $1 \mathrm{~m}^{3} \mathrm{~min}^{-1}$. One high-volume sampler collected $\mathrm{PM}_{2.5}$ for $23 \mathrm{~h}$ (08:00 to 07:00 the next day, local time), while the two remaining samplers collected $\mathrm{PM}_{2.5}$ in two cycles. When the sampling schedules were daytime (08:0019:00 LT) and nighttime (20:00-07:00 LT), the collection cycle and samples are defined as regular day-night sampling periods and samples. On selected days (10-12, 14-16 and 29-30 June, and 9-16 July), when high levels of isoprene, sulfate $\left(\mathrm{SO}_{4}^{2-}\right)$, and $\mathrm{NO}_{x}$ were predicted at the LRK site by FLEXPART and MOZART model simulations (see Supplement), $\mathrm{PM}_{2.5}$ were collected more frequently (08:00-11:00, 12:00-15:00, 16:00-19:00, and 20:00-07:00 LT) to capture the effects of anthropogenic pollution on isoprene SOA formation at higher time resolution by offline techniques. Such days are defined as intensive sampling periods and the samples as intensive samples. A total of $4723 \mathrm{~h}$ integrated samples, 2 sets of 64 intensive samples and 59 day-night filter samples were collected over the 6-week period of the campaign and stored at $-20^{\circ} \mathrm{C}$ until analysis. Field blanks were collected weekly by placing pre-baked quartz filters into the high-volume $\mathrm{PM}_{2.5}$ samplers for $15 \mathrm{~min}$ and then removing and storing them under the same conditions as the field samples.

\subsubsection{Instrumentation}

Gas chromatography/electron ionization-mass spectrometry (GC/EI-MS) was performed on a Hewlett Packard (HP) 5890 Series II Gas Chromatograph equipped with an Econo-Cap ${ }^{\circledR}$ -EC ${ }^{\circledR}$-5 Capillary Column ( $30 \mathrm{~m} \times 0.25 \mathrm{~mm}$ ID; $0.25 \mu \mathrm{m}$ film thickness) coupled to an HP 5971A Mass Selective Detector. GC/EI-MS operating conditions and temperature program are provided in Surratt et al. (2010).

Ultra performance liquid chromatography/diode array detector-electrospray ionization high-resolution quadrupole time-of-flight mass spectrometry (UPLC/DAD-ESI-HRQTOFMS) was performed on an Agilent 6500 series system equipped with a Waters Acquity UPLC HSS T3 col- umn $(2.1 \times 100 \mathrm{~mm}, 1.8 \mu \mathrm{m}$ particle size $)$. UPLC/DAD-ESIHR-QTOFMS operating conditions are described in Zhang et al. (2011).

\subsubsection{Isoprene-derived SOA tracer quantification}

Detailed filter extraction procedures are provided in Lin et al. (2013a). Briefly, from each filter two $37 \mathrm{~mm}$ punches (one for analysis by GC/EI-MS and one for UPLC/DADESI-HR-QTOFMS analysis) were extracted in separate precleaned scintillation vials with $20 \mathrm{~mL}$ high-purity methanol (LC-MS Chromasolv-grade ${ }^{\circledR}$, Sigma Aldrich) by sonication for $45 \mathrm{~min}$. Filter extracts were then filtered through $0.2 \mu \mathrm{m}$ syringe filters (Acrodisc ${ }^{\circledR}$ PTFE membrane, Pall Life Sciences) to remove suspended filter fibers and insoluble particles, and then gently blown down to dryness under an $\mathrm{N}_{2}$ (g) stream at room temperature.

The known IEPOX-derived SOA tracers, 2-methyltetrols (Claeys et al., 2004), C5-alkene triols (Wang et al., 2005), cisand trans-3-methyltetrahydrofuran-3,4-diols (3-MeTHF-3,4diols) (Lin et al., 2013b), and IEPOX-derived dimers (Surratt et al., 2006), and the known MAE-derived SOA tracer, 2methylglyceric acid (2-MG) (Edney et al., 2005), were identified by GC/EI-MS immediately following trimethylsilylation. Derivatization was performed by reaction with $100 \mu \mathrm{L}$ of BSTFA (N,O-bis(trimethylsilyl)trifluoroacetamide) + TMCS (trimethylchlorosilane) $(99: 1, v / v$, Supelco) and $50 \mu \mathrm{L}$ of pyridine (anhydrous, $99.8 \%$, Sigma Aldrich) at $70{ }^{\circ} \mathrm{C}$ for $1 \mathrm{~h} .1 \mu \mathrm{L}$ of derivatized sample was directly analyzed. Base peak ions of the corresponding tracers, $m / z$ 219 for 2-methyltetrols, $\mathrm{m} / \mathrm{z} 231$ for $\mathrm{C}_{5}$-alkene triols, $\mathrm{m} / \mathrm{z}$ 262 for 3-MeTHF-3,4-diols, $\mathrm{m} / \mathrm{z} 335$ for dimers, and $\mathrm{m} / \mathrm{z}$ 219 for 2-MG, were quantified using authentic standards of 2-methyltetrols (50:50, v/v, 2-C-methylerythritol and 2-Cmethylthreitol), cis- and trans-3-MeTHF-3,4-diols, and 2MG. The $\mathrm{C}_{5}$-alkene triols and dimers were quantified by the response factor obtained for the synthetic 2-methyltetrols. Synthetic procedures for cis- and trans-3-MeTHF-3,4-diols have been described previously by Zhang et al. (2012b). Synthesis of the tetrol mixture will be described in a forthcoming publication; the ${ }^{1} \mathrm{H}$ NMR trace (Fig. S13) shows a $1.2: 12$ C-methylerythritol and 2-C-methylthreitol of $>99 \%$ purity.

Organosulfates, including the 2-methyltetrol sulfate esters $\left(\left[\mathrm{C}_{5} \mathrm{H}_{11} \mathrm{O}_{7} \mathrm{~S}\right]^{-}, m / z 215\right)$, IEPOX dimer sulfate esters $\left(\left[\mathrm{C}_{10} \mathrm{H}_{21} \mathrm{O}_{10} \mathrm{~S}\right]^{-}, m / z\right.$ 333) (Surratt et al., 2008), and 2-MG sulfate ester $\left(\left[\mathrm{C}_{4} \mathrm{H}_{7} \mathrm{O}_{7} \mathrm{~S}\right]^{-}, m / z\right.$ 199) (Lin et al., 2013b), were analyzed by UPLC/DAD-ESI-HR-QTOFMS. The UPLC/DAD-ESI-HR-QTOFMS was operated in both negative and positive ion modes; however, only the negative ion mode data are presented here since the positive ion mode data were recently described in Lin et al. (2014). Filter extract residues were reconstituted with $150 \mu \mathrm{L}$ of a $50: 50$ $(v / v)$ solvent mixture of methanol (LC-MS Chromasolvgrade, Sigma Aldrich) and laboratory Milli-q water and a $5 \mu \mathrm{L}$ aliquot of each sample was eluted with solvent 
of the same composition. IEPOX-derived sulfate esters (2methyltetrol sulfate esters) were quantified using an authentic standard synthesized at UNC (The University of North Carolina), while sodium propyl sulfate was used to quantify the remaining isoprene-derived organosulfates. The 2methyltetrol sulfate ester standards were obtained and used as tetrabutylammonium salts. The synthetic procedure will be described in a forthcoming publication. The ${ }^{1} \mathrm{H}$ NMR trace (Fig. S14) shows the purity of the sulfate ester mixture is $>99 \%$. The response factor of the authentic sulfate ester standards from several analyses is a factor of $2.25 \pm 0.13$ lower than that of sodium propyl sulfate used in previous field studies (Lin et al., 2013a), suggesting that the IEPOX organosulfates likely make a contribution to mass concentration higher by a factor of $\sim 2.3$ than previously estimated at field sites. Table 1 summarized data for isoprene-derived SOA tracers quantified from 123 filter samples using the above techniques.

\subsubsection{Filter analysis of WSOC and OC constituents}

For analysis of water-soluble organic compound (WSOC) concentrations, additional filter punches $(47 \mathrm{~mm})$ were placed in pre-cleaned glass vials and extracted with 30 or $40 \mathrm{~mL}$ ultra pure water by sonication for $40 \mathrm{~min}$ at $1 \mathrm{kHz}$. Extracts were filtered through a syringe filter $(0.45 \mu \mathrm{m}, \mathrm{GE}$ Healthcare UK Limited, UK) to remove insoluble particles. Samples were extracted batch-wise, with each batch containing 12-21 ambient samples, one lab blank, and one sample spiked with $1000 \mu g \mathrm{gL}^{-1}$. Total organic carbon (TOC) was analyzed using a $5310 \mathrm{C}$ TOC analyzer and 900 inorganic carbon remover (ICR). The instrument was calibrated by single-point calibration with $1000 \mu \mathrm{gC} \mathrm{L}^{-1}$ of potassium hydrogen phthalate (KHP) and sodium carbonate. The calibration was verified with $1000 \mu \mathrm{gC} \mathrm{L} \mathrm{L}^{-1}$ of sucrose, and checked daily with a $1000 \mu \mathrm{gCL}^{-1}$ of KHP standard. Standards and samples were run in triplicate; the first data point was rejected and the following two averaged.

Total OC and elemental carbon (EC) measurements from filter samples were conducted at the National Exposure Research Laboratory, US Environmental Protection Agency, at Research Triangle Park, NC. A $1.5 \mathrm{~cm}^{2}$ punch was taken from each filter for OC/EC analysis using the thermal-optical method (Birch and Cary, 1996) on a Sunset Laboratory (Tigard, OR) OC/EC instrument. Table S4 provides temperature and purge gas settings for the method. The instrument was calibrated internally using methane gas and the calibration was verified with sucrose solution at four mass concentrations.

\subsection{Estimations of aerosol $\mathrm{pH}$ and IEPOX-derived SOA tracers}

The thermodynamic model, ISORROPIA-II (Fountoukis and Nenes, 2007; Nenes et al., 1999), is used to estimate aerosol
$\mathrm{pH}$. Inputs for the model include aerosol-phase sulfate, nitrate, and ammonium in $\mu \mathrm{mol} \mathrm{m}{ }^{-3}$, measured by the ACSM under ambient conditions; RH and temperature obtained from National Park Service (NPS); and gas-phase ammonia obtained from Ammonia Monitoring Network (AMoN; TN01/Great Smoky Mountains National Park - Look Rock). ISORROPIA-II predicted particle hydronium ion concentration per volume of air $\left(\mathrm{H}_{\text {air }}^{+}, \mu \mathrm{g} \mathrm{m}^{-3}\right)$, aerosol water (LWC, $\mu \mathrm{g} \mathrm{m}^{-3}$ ), and aerosol aqueous phase mass concentration $\left(\mu \mathrm{g} \mathrm{m}^{-3}\right)$. Aerosol $\mathrm{pH}$ is calculated by the following equation:

$\mathrm{pH}=-\log _{10} a_{\mathrm{H}^{+}}=-\log _{10}\left(\frac{\mathrm{H}_{\mathrm{air}}^{+}}{\mathrm{LMASS}} \times \rho_{\mathrm{aer}} \times 1000\right)$,

where $a_{\mathrm{H}^{+}}$is $\mathrm{H}^{+}$activity in aqueous phase $\left(\mathrm{molL}^{-1}\right)$, LMASS is the total liquid-phase aerosol mass $\left(\mu \mathrm{g} \mathrm{m}^{-3}\right)$ and $\rho_{\text {aer }}$ is aerosol density $\left(\mathrm{g} \mathrm{cm}^{-3}\right)$. The ability of ISORROPIA to capture $\mathrm{pH}, \mathrm{LWC}$ and gas-to-particle partitioning of inorganic volatiles (e.g., $\mathrm{NH}_{3}, \mathrm{HNO}_{3}, \mathrm{HCl}$ ) has been the focus of other studies (Fountoukis et al., 2009; Guo et al., 2015) and is not further discussed here.

IEPOX-derived SOA tracers are estimated using simpleGAMMA (Woo and McNeill, 2015). It is a reduced version of GAMMA (Gas Aerosol Model for Mechanism Analysis), the detailed photochemical box model of aqueous aerosol SOA (aqSOA) formation developed by McNeill and coworkers (McNeill et al., 2012). GAMMA and simpleGAMMA represent aqSOA formation in terms of bulk aqueous uptake followed by aqueous-phase reaction (Schwartz, 1986). For this study, we utilized only the aqueous aerosol-phase chemistry of IEPOX to predict IEPOXderived SOA constituents. We applied the Henry's law constant of $3 \times 10^{7} \mathrm{M} \mathrm{atm}^{-1}$ for IEPOX partitioning based on measurements by Nguyen et al. (2014) on deliquesced $\mathrm{NaCl}$ particles. Estimation of 2-methyltetrols and IEPOX-derived organosulfate masses in the aqueous phase was based on the Eddingsaas et al. (2010) mechanism:

$\operatorname{IEPOX}(\mathrm{aq}) \rightarrow(1-\beta) \cdot 2$ methyltetrols $+\beta \cdot$ IEPOXorganosulfate,

where $\beta$ is a branching ratio between 2-methyltetrols and IEPOX-derived organosulfate concentration. We applied $\beta=0.4$ based on the observation of Eddingsaas et al. (2010) for the most concentrated bulk solution they studied. The rate constant for Eq. (2) $(k a)$ is a function of $a_{\mathrm{H}^{+}}$and nucleophile concentrations (Eddingsaas et al., 2010), modified to include the possible protonation of IEPOX (aq) by ammonium (Nguyen et al., 2014):

$$
\begin{aligned}
& k a=k_{\mathrm{H}^{+}} a_{\mathrm{H}^{+}}+k_{\mathrm{SO}_{4}{ }^{2-}}\left[\mathrm{SO}_{4}{ }^{2-}\right] a_{\mathrm{H}}^{+} \\
& +k_{\mathrm{HSO}_{4}}^{-}\left[\mathrm{HSO}_{4}^{-}\right]+k_{\mathrm{NH}_{4}^{+}}\left[\mathrm{NH}_{4}^{+}\right] . \\
& \mathrm{Here}, k_{\mathrm{H}^{+}}=5 \times 10^{-2} \mathrm{~s}^{-1}, k_{\mathrm{SO}_{4}^{2-}}=2 \times 10^{-4} \mathrm{M}^{-1} \mathrm{~s}^{-1} \text {, and } \\
& k_{\mathrm{HSO}_{4}^{-}}=7.3 \times 10^{-4} \mathrm{M}^{-1} \mathrm{~s}^{-1} \text {. The ammonium rate constant, }
\end{aligned}
$$


Table 1. Summary of isoprene-derived SOA tracers measured by GC/EI-MS and UPLC/DAD-ESI-HR-QTOFMS.

\begin{tabular}{|c|c|c|c|c|c|}
\hline \multirow[t]{2}{*}{ SOA Tracers } & \multirow{2}{*}{$\begin{array}{r}\text { Retention Time } \\
(\mathrm{min})\end{array}$} & \multirow{2}{*}{$\begin{array}{c}\text { \# of Samples } \\
\text { Detected }^{*}\end{array}$} & \multicolumn{2}{|c|}{ Concentration $\left(\mathrm{ng} \mathrm{m}^{-3}\right)$} & \multirow{2}{*}{$\begin{array}{l}\text { Average } \% \text { among } \\
\text { detected tracers }\end{array}$} \\
\hline & & & Maximum & Mean & \\
\hline \multicolumn{6}{|l|}{ Tracers by GC/EI-MS } \\
\hline trans-3-MeTHF-3,4-diol & 20.5 & 55 & 18.8 & 2.7 & $0.2 \%$ \\
\hline cis-3-MeTHF-3,4-diol & 21.1 & 29 & 5.7 & 1.7 & $0.1 \%$ \\
\hline 2-methylglyceric acid & 23.4 & 119 & 36.7 & 7.5 & $1.5 \%$ \\
\hline 2-methylthreitol & 32.9 & 122 & 329.8 & 42.4 & $8.6 \%$ \\
\hline 2-methylerythritol & 33.7 & 122 & 1269.7 & 120.7 & $24.4 \%$ \\
\hline (Z)-2-methylbut-3-ene-1,2,4-triol & 25.6 & 121 & 260.0 & 29.1 & $5.8 \%$ \\
\hline 2-methylbut-3-ene-1,2,3-triol & 26.6 & 118 & 162.5 & 16.5 & $3.2 \%$ \\
\hline (E)-2-methylbut-3-ene-1,2,4-triol & 26.9 & 122 & 1127.0 & 98.8 & $19.9 \%$ \\
\hline \multicolumn{6}{|c|}{ Tracers by UPLC/DAD-ESI-HR-QTOFMS } \\
\hline IEPOX-derived organosulfates & $1.1-1.7$ & 122 & 1135.3 & 169.5 & $34.2 \%$ \\
\hline IEPOX-derived dimer organosulfate & 2.8 & 103 & 14.0 & 1.4 & $0.2 \%$ \\
\hline MAE-derived organosulfate & 1.1 & 114 & 77.9 & 10.0 & $1.9 \%$ \\
\hline
\end{tabular}

* Total number of samples is 123 .

$k_{\mathrm{NH}_{4}^{+}}$, was calculated using GAMMA and the results of the chamber study of Nguyen et al. (2014) are $1.7 \times$ $10^{-5} \mathrm{M}^{-1} \mathrm{~s}^{-1}$.

IEPOX uptake and formation of 2-methyltetrols and IEPOX-derived organosulfate was computed using simpleGAMMA with inputs of $\mathrm{SO}_{4}^{2-}, \mathrm{HSO}_{4}^{-}, \mathrm{NH}_{4}^{+}, \mathrm{LWC}$, $a_{\mathrm{H}^{+}}$concentrations $\left(\mathrm{mol} \mathrm{L}^{-1}\right)$, and aerosol $\mathrm{pH}$ estimated by ISORROPIA-II simulation of field conditions, ambient temperature and $\mathrm{RH}$, aerosol surface area $\left(\mathrm{cm}^{2} \mathrm{~cm}^{-3}\right)$ obtained from SEMS-MCPC measurements, and IEPOX concentration $\left(\mathrm{mol} \mathrm{cm}^{-3}\right)$ from acetate CIMS (Sect. 2.4). Masses of SOA tracers formed over $12 \mathrm{~h}$ are compared with measurements in Sect. 3.4.2.

\section{Results and discussion}

\subsection{Fine aerosol component mass concentrations}

Chemical measurements of fine aerosol made by the ACSM and collocated instruments are presented in Fig. 1. The ACSM measured a campaign average $7.6 \pm 4.7 \mu \mathrm{g} \mathrm{m}^{-3}$ of NR-PM ${ }_{1}$, which is predominantly organic aerosol $(64.1 \%)$. Sulfate aerosol $(24.3 \%)$ is the most dominant inorganic aerosol component, followed by ammonium $(7.7 \%)$, nitrate $(3.8 \%)$, and chloride $(0.1 \%)$. The NR-PM $\mathrm{PM}_{1}$ mass measured at the site shows strong association $\left(r^{2}=0.89\right)$ with the SEMS-MCPC PM 1 mass measurements (Figs. 1d and S3).

Moderate correlations, depicted in Fig. S15 were observed between ACSM OM and filter OC and WSOC $\left(r^{2}=0.54\right.$, 0.39 , respectively) as well as between filter OC and WSOC measurements $\left(r^{2}=0.36\right)$, suggesting that fractions of OM and OC at LRK site are water-soluble as previously observed (Turpin and Lim, 2001). This water-soluble fraction may be associated with high isoprene emissions in this area (Zhang

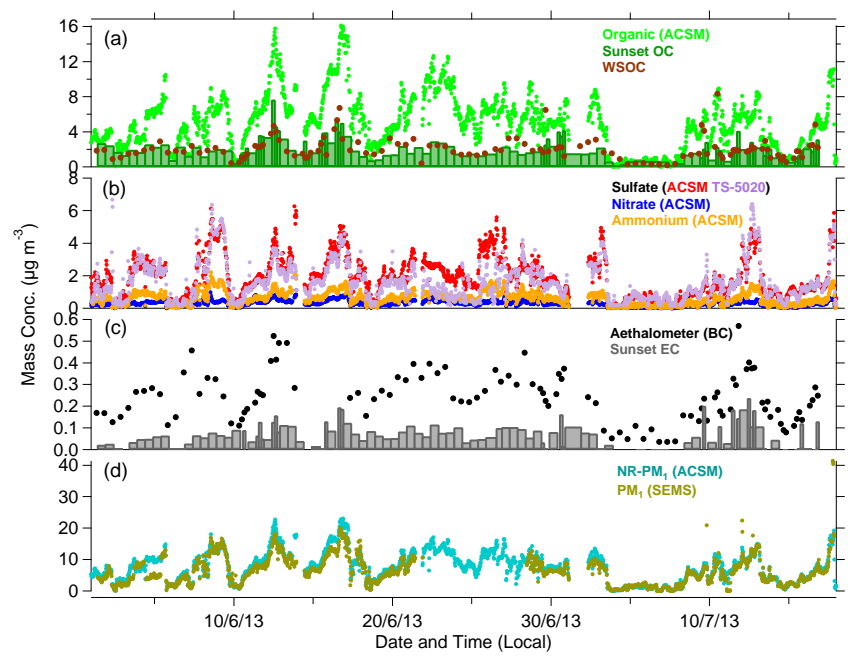

Figure 1. Time series mass concentration of (a) organic and (b) inorganics (excluding chloride) measured by ACSM, (c) black carbon (BC) measured by Aethalometer, and (d) NR-PM 1 and $\mathrm{PM}_{1}$ mass concentrations measured by ACSM and SEMS-MCPC. Collocated sulfate aerosol measured by Thermo Scientific Sulfate Analyzer was plotted on (b). OC (bars) and WSOC (dots), both in unit of $\mu \mathrm{gC} \mathrm{m}{ }^{-3}$, measured from filter samples were plotted on (a) with ACSM organic. EC (bars; in unit of $\mu \mathrm{gC} \mathrm{m}^{-3}$ ) measured from filter samples were plotted on (c) along with $\mathrm{BC}$ measurements.

et al., 2012a). Lewis et al. (2004) reported that $56-80 \%$ of total carbon in $\mathrm{PM}_{2.5}$ samples collected during summer in Nashville, TN, was non-fossil carbon, supporting the importance of biogenic SOA in the southeastern US during summer. It is potentially possible that some fraction of this nonfossil carbon is associated to biomass burning ( $\mathrm{Ke}$ et al., 2007). A more recent study found that non-fossil carbon accounts for $50 \%$ of carbon at two urban sites and $70-100 \%$ of 
carbon at 10 near-urban or remote sites in the US (Schichtel et al., 2008). In summer 2001, the fraction of non-fossil carbon was reported to vary from $66-80 \%$ of total carbon at the LRK, TN site, suggesting the importance of photochemical oxidation of biogenic VOCs (Tanner et al., 2004). The slope of the linear regression analysis on Fig. S15a indicates an OM : OC ratio of 2.34 and OM : WSOC ratio of 2.19. Using the Aiken et al. (2008) parameterization approach, we found an average $( \pm 1-\sigma) \mathrm{OM}$ : OC ratio of $2.14( \pm 0.18)$. The LRK $\mathrm{OM}: \mathrm{OC}$ ratios obtained from measurements and parameterization are consistent with a previous study at Look Rock (2.1) (Turpin and Lim, 2001), but higher than those measured at Centerville, AL (1.77) (Sun et al., 2011), probably ascribable to different atmospheric aerosol properties at the two sites.

Elemental analyses of ACSM unit-mass resolution data using the Aiken et al. (2008) parameterization results in an average $\mathrm{O}: \mathrm{C}$ ratio of $0.77 \pm 0.12$. This is within $0.6-1$ of $\mathrm{O}: \mathrm{C}$ ratio previously observed in the southeastern US (Centerville, AL) (Sun et al., 2011; Xu et al., 2015).

ACSM sulfate aerosol measurements (average of $\left.1.85 \pm 1.23 \mu \mathrm{g} \mathrm{m}^{-3}\right)$ agree well $\left(r^{2}=0.67\right.$, slope 1.08$)$ with the collocated sulfate measurements (Table S1), demonstrating that ACSM performed well when compared to existing air quality monitoring instruments as previously reported (Budisulistiorini et al., 2014). Low nitrate concentration is expected due to the high summer temperatures $\left(15-31^{\circ} \mathrm{C}\right)$ and low prevailing $\mathrm{NO}_{x}$ concentrations $(0.1-2 \mathrm{ppb})$ measured at the site. In the absence of a significant source of chloride, chloride concentrations were predictably low $\left(0.01 \pm 0.01 \mu \mathrm{g} \mathrm{m}^{-3}\right)$.

On average, mass concentration of $\mathrm{BC}$ was $0.23 \pm 0.14 \mu \mathrm{g} \mathrm{m}^{-3}$ or about $3 \%$ of total $\mathrm{PM}_{2.5}$ measured at the site. The low relative contribution was consistent during the campaign except on 11 to 12 July when there was a significant increase during a few hours overnight. EC measured from filters was even lower at $0.06 \mu \mathrm{g} \mathrm{m}^{-3}$ on average and was only weakly correlated $\left(r^{2}=0.32\right)$ with BC. Carbon monoxide (CO), another primary species measured at LRK, was also low (115.62 $\pm 24.06 \mathrm{ppb}$ on average) throughout the campaign. A previous study found that the level of primary species increased during mid-morning when the boundary layer height reached the site, and declined later in the day as a result of dilution (Tanner et al., 2005). In contrast, secondary species such as $\mathrm{PM}_{2.5}$ and sulfate do not show significant diurnal variability, suggesting local meteorological conditions are less influential in determining concentrations of the long-lived species (Tanner et al., 2005, 2015). The overall low concentration of primary emissions at the site (Fig. S16) is consistent with minimum local and/or regional primary emissions.

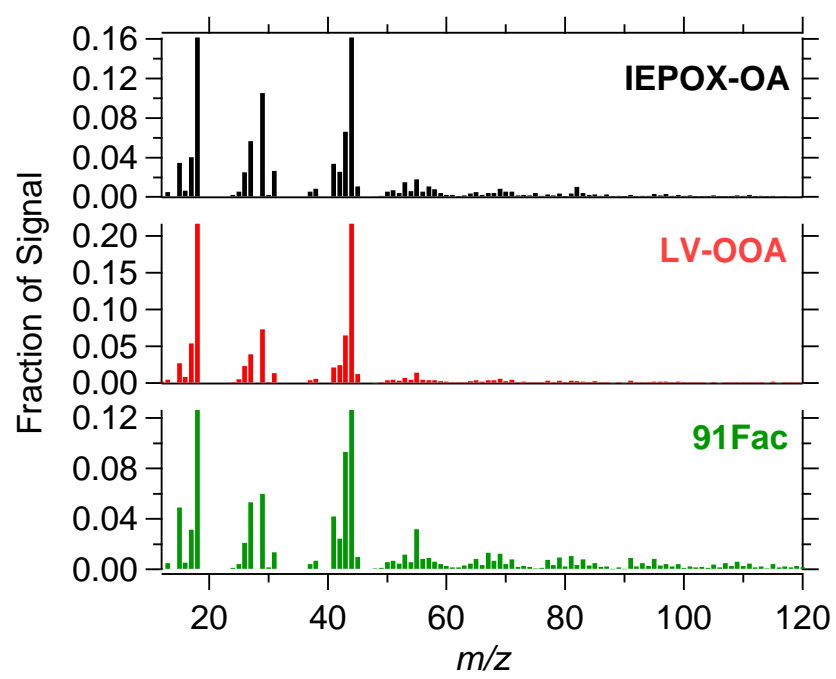

Figure 2. Mass spectra obtained for the 3-factor solution from PMF: IEPOX-OA, LV-OOA, and 91 Fac.

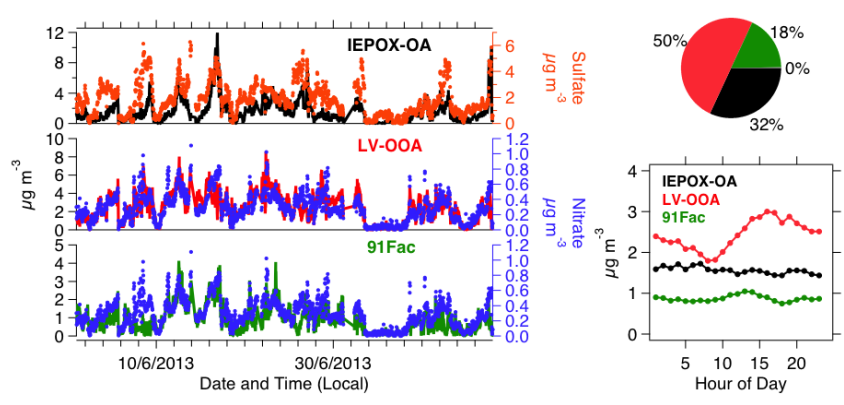

Figure 3. Left panel shows the PMF 3-factor solution time series mass contributions measured by ACSM. Top to bottom: left ordinate, IEPOX-OA (black), LV-OOA (red), and 91 Fac (green); right ordinate, sulfate (orange) and nitrate (blue). Right panel shows average mass contributions (top) and diurnal variation (bottom) of factors resolved by PMF.

\subsection{Source apportionment of OA from the ACSM}

PMF analysis was conducted on the ACSM OA mass spectral data in order to resolve factors (or source profiles) without a priori assumptions. A 3-factor solution resolved from PMF analysis, as shown in Figs. 2 and 3, was selected as the bestfit (see Supplement for details of $Q / Q_{\text {exp }}, f_{\text {peak }}$, etc.), comprised of the known LV-OOA factor (Jimenez et al., 2009; Ulbrich et al., 2009), an IEPOX-OA factor (Budisulistiorini et al., 2013; Slowik et al., 2011; Robinson et al., 2011), and a factor similar to $91 \mathrm{Fac}$, a factor previously observed in areas dominated by biogenic emissions (Robinson et al., 2011; Slowik et al., 2011; Chen et al., 2015).

The IEPOX-OA factor resolved from our data set is more closely correlated to sulfate measured by the ACSM $\left(r^{2}=0.58\right)$ than by the collocated instrument $\left(r^{2}=0.31\right)$ (Table S5). Correlation of gaseous IEPOX measured by ac- 
Table 2. Correlation $\left(r^{2}\right)$ of PMF factors with isoprene-derived SOA tracers measured by GC/EI-MS and UPLC/DAD-ESI-HRQTOFMS.

\begin{tabular}{lccc}
\hline SOA Tracers & IEPOX-OA & LV-OOA & 91Fac \\
\hline 3-methyltetrahydrofuran-3,4-diols & 0.12 & 0.13 & 0.24 \\
2-methyltetrols & 0.80 & 0.20 & 0.38 \\
C5-alkene triols & 0.75 & 0.19 & 0.44 \\
2-methylglyceric acid & 0.38 & 0.44 & 0.44 \\
IEPOX-derived organosulfates & 0.76 & 0.29 & 0.42 \\
IEPOX-derived dimer organosulfate & 0.71 & 0.12 & 0.34 \\
MAE-derived organosulfate & 0.37 & 0.44 & 0.52 \\
\hline
\end{tabular}

etate CIMS with the IEPOX-OA factor is low $\left(r^{2}=0.24\right)$, which may be a consequence of the time gap from IEPOX uptake onto sulfate aerosol process which can take up $\sim 5 \mathrm{~h}$ in the presence of aqueous, highly acidic aerosol $(\mathrm{pH} \leq 1)$ (Gaston et al., 2014). The time gap between formation of gaseous IEPOX and IEPOX-OA factor could be wider due to ISOPOOH, which lifetime to $\mathrm{OH}$ is $3-5 \mathrm{~h}$ (Paulot et al., 2009), interference on IEPOX signal measured by acetate acetate CIMS. Importantly, the IEPOX-OA factor correlates strongly with 2-methyltetrols $\left(r^{2}=0.80\right)$, IEPOX-derived organosulfates $\left(r^{2}=0.81\right), \mathrm{C}_{5}$-alkene triols $\left(r^{2}=0.75\right)$, and dimers of organosulfates $\left(r^{2}=0.73\right)$ (Table 2), giving an overall $r^{2}$ of 0.83 with sum of IEPOX-derived SOA tracers measured by offline techniques. The high correlation provides strong evidence that IEPOX chemistry gives rise to the PMF factor we have designated as the IEPOX-OA factor. The contribution of this factor to total OM is $32 \%$, which is strikingly consistent with the contribution of the factor designated as the IEPOX-OA factor in the PMF analysis of fine organic aerosol collected in downtown Atlanta, GA (Budisulistiorini et al., 2013) and across other sites in this region (Xu et al., 2015). IEPOX-OA was not only formed on site but could also transported from surrounding forested and isoprene-rich areas. The reactive-uptake of IEPOX is influenced by aerosol sulfate (Lin et al., 2012) that is not formed on site, might explain the lack of significant diurnal variation (Fig. 3) of the IEPOX-OA factor at LRK. WSOC shows fair correlation with some IEPOX-OA tracers $\left(r^{2}=0.3-0.4\right.$; Table S6) and IEPOX-OA factor $\left(r^{2}=0.37\right.$; Table S5) the nature of which will be discussed in more detail below.

The LV-OOA factor contributes $50 \%$ of OM (Fig. 3). The average $f_{44}=0.22$ is comparable to that of the standard LVOOA profile ( $\mathrm{Ng}$ et al., 2011), suggesting it is an oxidized (aged) aerosol. The LV-OOA correlated well with nitrate $\left(r^{2}=0.62\right)$ but more weakly with sulfate $\left(r^{2}=0.39\right)($ Table S5). Correlation with nitrate as well as the high level of oxidation is consistent with the suggestion above that a fraction of OA originates from the valley. Located on a ridge top above the morning valley fog, LRK receives air masses from the valley as the boundary layer rises during the day (Tanner et al., 2005). Diurnal profile of LV-OOA observed at LRK is similar to more-oxidized OOA (MO-OOA) observed at Cen-

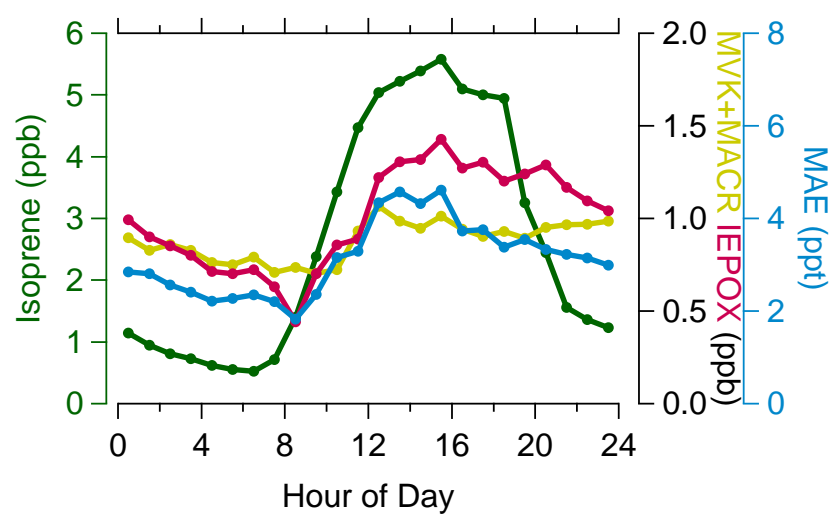

Figure 4. Diurnal variation of isoprene (left ordinate) as well as isoprene gaseous 3 photooxidation products (right ordinates), i.e., MVK+MACR, IEPOX and MAE, measured at LRK site. It should be noted that IEPOX signal includes interference of ISOPOOH at unknown ratio; thus its mixing ratio represents an upper limit.

terville (Xu et al., 2015), suggesting their regional sources. At LRK average mixing ratios of monoterpenes and isoprene were $<1 \mathrm{ppb}$ and $\sim 2 \mathrm{ppb}$ (Fig. 4 ), respectively. Low anthropogenic emissions at LRK ( $<1 \mathrm{ppb}$; Fig. S16) suggests that BVOCs (biogenic VOCs) could be the source of LV-OOA (50\% of OA) formation. Anthropogenic emissions as well as nitrate chemistry in the valley could also influence LV-OOA formation that oxidized during transport to the LRK site.

The 91Fac factor is characterized by a distinct ion at $\mathrm{m} / \mathrm{z}$ 91. At LRK, the average $f_{44}$ of $91 \mathrm{Fac}$ is 0.12 , between the values 0.05 and 0.16 reported for standard SV-OOA and LVOOA profiles, respectively (Ng et al., 2011), indicating that it is likely an oxygenated OA. The LRK 91Fac makes the smallest contribution to OM (18\%) of the three factors resolved by PMF analysis. The 91Fac diurnal pattern shows slight increases during noon and night, suggesting that this factor might be affected by both photochemistry and nighttime chemistry. Potential sources of $91 \mathrm{Fac}$ is discussed in more detail in the Supplement (Fig. S17) and its association with biogenic SOA chemistry will be the focus of future studies.

A source apportionment study of organic compounds in $\mathrm{PM}_{2.5}$ at LRK during August 2002 using the chemical mass balance (CMB) model evaluated contributions by eight primary sources, chosen as representing the major contributors to fine primary OC in the southeast US. Primary sources, consisting largely of wood burning, were estimated to contribute $\sim 14 \%$ of the total OC at LRK (Ke et al., 2007). ${ }^{14} \mathrm{C}$ Analysis of the LRK PM 2.5 in the same study showed that during summer, $\sim 84 \%$ of the OC was non-fossil carbon (Ke et al., 2007). By contrast, our current study resolved no POA by PMF analysis. However, in subsequent studies, we will investigate the influence of POA at LRK by examining the ${ }^{14} \mathrm{C}$ data from filter samples. 


\subsection{Identification and quantification of isoprene-derived SOA tracers}

2-Methylglyceric acid, 2-methyltetrols, $\mathrm{C}_{5}$-alkene triols and IEPOX-derived organosulfates were detected in most filter samples (Table 1). Among all observed SOA tracers, 2-C-methylerythritol and 2-methylbut-3-ene-1,2,4-triol were the most abundant species identified by GC/EI-MS, contributing $\sim 24 \%\left(120.7 \mathrm{ng} \mathrm{m}^{-3}\right.$ on average) and $\sim 20 \%$ (98.8 $\mathrm{ng} \mathrm{m}^{-3}$ on average), respectively, of total quantified mass, while isomeric IEPOX-derived organosulfates accounted for $\sim 34 \%$ (169.5 $\mathrm{ng} \mathrm{m}^{-3}$ on average) of the mass detected by UPLC/DAD-ESI-HR-QTOFMS. Concentrations of the isomeric 3-MeTHF-3,4-diols were lower ( $\leq 18.8 \mathrm{ng} \mathrm{m}^{-3}$ ), often at or below detection limits. Gaseous IEPOX was on average $1 \mathrm{ppb}$ (maximum $5.8 \mathrm{ppb}$ ) significantly higher than gaseous MAE at $2.8 \times 10^{-3} \mathrm{ppb}$ on average (maximum $0.02 \mathrm{ppb}$ ). This explains the abundance of IEPOX-derived SOA tracers compared to MAE-derived tracers. It should be noted that IEPOX quantified here includes the interference of ISOPOOH on its signal; however, the overall measured IEPOX signal is still substantially higher than the MAE signal, even if we assume IEPOX only contributes to $1-10 \%$ of the $m / z 177$ intensity.

In sum, IEPOX- and MAE-derived tracers contributed 96.6 and $3.4 \%$, respectively, of total isoprene-derived SOA mass quantified from filter samples. This observation is consistent with a previous field study in Yorkville, GA, which reported the summed IEPOX-derived SOA tracers comprised $97.5 \%$ of the quantified isoprene-derived SOA mass (Lin et al., 2013a). Total IEPOX-derived tracers masses quantified from filter samples were on average $26.3 \%$ (maximum $48.5 \%$ ) of the IEPOX-OA factor mass resolved by PMF. This is consistent with a recent laboratory study of isoprene photooxidation under high $\mathrm{HO}_{2}$ conditions that suggested IEPOX isomers contributed about $50 \%$ of SOA mass formed (Liu et al., 2014).

Masses of IEPOX- and MAE-derived SOA tracers were fairly correlated $\left(r^{2}=0.37\right.$ and 0.29 , respectively) with WSOC (Fig. S15c). Around $26 \%$ of the WSOC mass might be explained by IEPOX-derived SOA tracer masses, which consist predominantly of 2-methyltetrols, $\mathrm{C}_{5}$-alkene triols, and IEPOX-derived organosulfates. The tetrols and triols are hydrophilic compounds owing to the $\mathrm{OH}$ groups, and the organosulfates are ionic polar compounds (Gómez-González et al., 2008).

An interesting and potentially important observation is that oligomeric IEPOX-derived humic-like substances (HULIS) have been reported in both reactive uptake experiments onto acidified sulfate seed aerosol and in ambient fine aerosol from the LRK and Centerville sites during the SOAS campaign (Lin et al., 2014). The HULIS is a mixture of hydroxylated, sulfated as well as highly unsaturated, light-absorbing components which may partition between WSOC and water insoluble organic carbon (WISC) fractions (Lin et al., 2014). This finding might also in part explain the moderate correlation between WSOC and the IEPOX-OA factor. However, HULIS has not been quantified here due to the lack of authentic standards, but will likely help to close the IEPOX-OA mass budget once appropriate standards are developed and applied. As quantified by ACSM, summed isoprene-derived SOA tracers on average accounted for $0.5 \mu \mathrm{g} \mathrm{m}^{-3}$ or $9.4 \%$ (up to $4.4 \mu \mathrm{g} \mathrm{m}^{-3}$ or $28.1 \%$ ) of the average organic aerosol mass of $5.1 \mu \mathrm{g} \mathrm{m}^{-3}$ (maximum $15.3 \mu \mathrm{g} \mathrm{m}^{-3}$ ) during the campaign. This contribution is somewhat lower than reported at a different rural site in the southeast US (13.6-19.4\%) (Lin et al., 2013a) but higher than reported at a forested site in central Europe (6.8\%) (Kourtchev et al., 2009) and a rural site in south China (1.6\%) (Ding et al., 2012). It should be noted that in all previous studies sulfate esters of 2-methyltetrol were quantified by surrogate standard structurally unrelated to the target analytes (i.e., sodium propyl sulfate). While in current study, a mixture of authentic 2-methyltetrol sulfate esters was used as a standard for quantifying IEPOX-derived organosulfates. The use of structurally unrelated surrogate standards may account in part for discrepancies between this and previous studies in which total isoprene SOA mass may have been underestimated as a result of higher instrument response to surrogates and/or lower recovery in sample preparation. These possibilities warrant further investigation using the same analytical protocols and comparison of instrumental responses to authentic and surrogate standards.

\subsection{Influence of anthropogenic emissions on isoprene-derived SOA formation at Look Rock}

\subsubsection{Effects of aerosol acidity and nitrogen-containing species}

The time series of aerosol $\mathrm{pH}$ estimated by ISORROPIAII overlaid on the time series of the IEPOX-OA factor and IEPOX- and MAE-derived SOA tracers (Fig. 5a, Tables S5S6) suggests that local aerosol acidity is not correlated with these measured variables. The correlation coefficients of the IEPOX-OA factor with ISORROPIA-II estimated $\mathrm{pH}$ and LWC bears out this conclusion $\left(r^{2} \sim 0\right.$; Table S5). These results are consistent with recent measurements reported by $\mathrm{Xu}$ et al. (2015) across several sites in the southeastern US. Aerosol acidity can be expected to change during transport and aging. Further complicating factors may be viscosity or morphology changes of the aerosol as IEPOX is taken up by heterogeneous reaction, and thus, slowing of uptake kinetics as the aerosol surface is coated with a hydrophobic organic layer (Gaston et al., 2014). Additionally, liquid-liquid phase separation is likely to occur in the atmosphere due to changes of relative humidity that affect particles water content (You et al., 2012). Moreover, the effects of aerosol viscosity and morphology on IEPOX uptake is not well understood and warrant further study using aerosol of complex mixtures and 


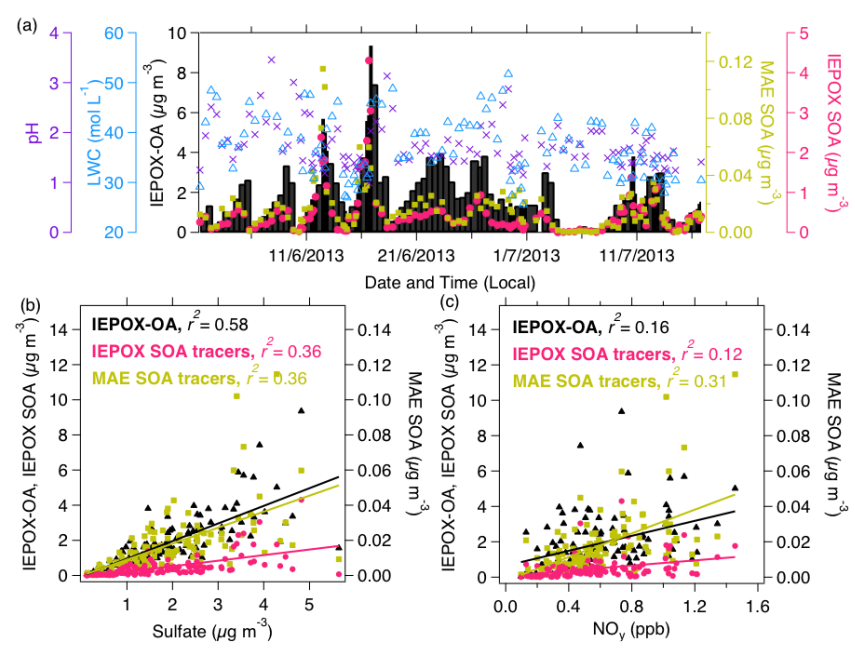

Figure 5. (a) Time series of IEPOX-OA factor (black bars; darker bars are intensive filter sampling periods), sum of IEPOXderived (pink circle) and MAE-derived (yellow square) SOA tracers, aerosol $\mathrm{pH}$ (purple cross) and LWC (blue triangle) estimated by ISORROPIA-II model. Campaign average $\mathrm{pH}$ and LWC are $1.78 \pm 0.53$ and $38.71 \pm 7.43 \mathrm{~mol} \mathrm{~L}^{-1}$, respectively. Correlation plots between IEPOX-OA, summed of IEPOX- and MAE-derived SOA tracers and (b) sulfate measurements by ACSM and (c) $\mathrm{NO}_{y}$ measurements from NPS.

of atmospheric relevance. Interpretation of the apparent lack of relationship between SOA and local aerosol acidity suggests that aerosol acidity is likely not the limiting factor in isoprene SOA formation at this site, especially since aerosol was consistently acidic during SOAS. The IEPOX-OA factor is moderately correlated with aerosol sulfate measured by ACSM $\left(r^{2}=0.58\right)$, while IEPOX- and MAE-derived SOA tracers are less correlated $\left(r^{2} \sim 0.4\right)$ (Fig. 5b). Correlation between sulfate and IEPOX-OA factor is consistent with recent measurements by Xu et al. (2015), and suggests the need for aerosol surface area due to acidic sulfate for these heterogeneous reactions to occur leading to IEPOX-OA formation.

Correlation of IEPOX-OA and isoprene-derived SOA tracers with $\mathrm{NO}_{x}, \mathrm{NO}_{y}$, and reservoir species $\left(\mathrm{NO}_{z}=\mathrm{NO}_{y}-\mathrm{NO}_{x}\right)$ was also examined. None of the nitrogen species showed significant association with either the IEPOX-OA factor $\left(r^{2}<0.1\right.$; Table S5) or the IEPOX-derived SOA tracers $\left(r^{2}<0.3\right.$; Table S5). Absence of correlations suggest the following: (1) the formation of isoprene SOA primarily through the low-NO pathway of isoprene photooxidation (Paulot et al., 2009; Surratt et al., 2010), (2) the isoprene oxidation did not happen locally, and (3) the gas-phase isoprene oxidation is not yet fully understood. Correlation plot of $\mathrm{NO}_{y}$, a measure of total reactive nitrogen species including MPAN, with summed MAE tracers is shown in Fig. 5c and correlation values of $\mathrm{NO}_{x}$ with individual compounds are given in Table S6. Besides being derived solely from the hydrolysis of MAE, 2-MG is also proposed to be the hydrolysis product of hydroxymethyl-methyl- $\alpha$ lactone (HMML) (Nguyen et al., 2015) and fair correlation between $\mathrm{NO}_{y}$ and 2-MG $\left(r^{2}=0.38\right)$ is consistent with this hypothesis. The correlation of the high- $\mathrm{NO}_{x}$ isoprene SOA tracers (2-MG and its corresponding organosulfate) with $\mathrm{NO}_{y}$ is suggesting that other pathways like the uptake and hydrolysis of MAE could be a source, especially since the further oxidation of MACR has been shown to yield MAE directly (Lin et al., 2013b). The observation that neither the summed MAE/HMML-derived tracers nor 2-MG correlated with $\mathrm{NO}_{x}$, is consistent with the hypothesis that MAE/HMML is formed in urban areas upwind and transported to the sampling site. Furthermore, it suggests that likely both HMML and MAE could be sources of these tracers.

In addition to the pattern of daily up-slope transport of air from the valley, air mass back-trajectory during high IEPOXderived SOA episodes (Fig. S18) indicated that air masses also originated west of LRK, in the direction of the urban areas of Knoxville and Nashville, TN. Yet further west of the LRK site are the Missouri Ozarks, a large source of isoprene emissions (referred to as the "isoprene volcano") (Guenther et al., 2006). During summer, isoprene emitted in the Ozarks could mix with anthropogenic emissions from Knoxville and Nashville, undergoing atmospheric processing during transport. As a consequence, long distance transport and accompanying oxidative processing may make a contribution to the IEPOX SOA loading at LRK. During low IEPOX-derived SOA periods (Fig. S19) air masses originated predominantly from the south and southwest, which are densely forested, rural areas.

\subsubsection{Box modeling supports the impact of aqueous cidic aerosol on IEPOX-derived SOA}

The IEPOX-derived SOA tracers (2-methyltetrols and IEPOX-derived organosulfate) predicted using simpleGAMMA, taking the locally measured IEPOX and aerosol parameters as inputs, show good correlation $\left(r^{2}=0.5-0.7\right)$ with the tracers quantified from filter samples (Table 3, Fig. S20). Slopes of the scatterplots show that the model overestimated the 2-methyltetrols and IEPOX-derived organosulfates by factors of 6.3 and 7.5, respectively. The simpleGAMMA model calculates Henry's Law gas-aqueous equilibration at each time step and decouples the subsequent aqueous-phase chemistry of IEPOX from dissolution (McNeill et al., 2012). In this study, we assumed an effective Henry's law constant, $\mathrm{H}^{*}$, of $3 \times 10^{7} \mathrm{M} \mathrm{atm}^{-1}$ for IEPOX, following the recent laboratory measurements of Nguyen et al. (2014), whereas previous studies assumed values which ranged 1 order of magnitude higher $\left(1.3 \times 10^{8} \mathrm{M} \mathrm{atm}^{-1}\right.$; Eddingsaas et al., 2010) or lower $\left(2.7 \times 10^{6} \mathrm{M} \mathrm{atm}^{-1}\right.$; Pye et al., 2013). Replacing the $\mathrm{H}^{*}$ with that of Pye et al. (2013), the model underestimated the 2-methyltetrols and IEPOX-derived organosulfates by 56 and $43 \%$, respectively. 
Table 3. Correlation $\left(r^{2}\right)$ of modeled SOA tracers with measurements.

\begin{tabular}{ccccc}
\hline $\mathrm{H}^{*}\left(\mathrm{M} \mathrm{atm}^{-1}\right)$ & \multicolumn{2}{c}{ 2-methyltetrols } & \multicolumn{2}{c}{ IEPOX organosulfates } \\
\cline { 2 - 5 } & $r^{2}$ & Slope & $r^{2}$ & Slope \\
\hline $3.0 \times 10^{7^{\mathrm{a}}}$ & 0.45 & $9.61 \pm 0.91$ & 0.66 & $10.65 \pm 0.73$ \\
$2.7 \times 10^{6^{\mathrm{b}}}$ & 0.44 & $0.69 \pm 0.06$ & 0.66 & $0.90 \pm 0.06$ \\
\hline
\end{tabular}

a Nguyen et al. (2014) and ${ }^{\mathrm{b}}$ Pye et al. (2013).

Decreasing the $\mathrm{H}^{*}$ by 1 order of magnitude yielded a factor of $\sim 10$ decrease in the predicted IEPOX SOA tracers mass, which is consistent with Pye et al. (2013) observation in sensitivity studies that a factor of 7 increase in $\mathrm{H}^{*}$ yielded a factor of $\sim 5$ increase in predicted IEPOX SOA yield. Similarly, summed masses of the modeled SOA tracers (Fig. 6) yielded a $141 \%\left(r^{2}=0.62\right)$ overestimate of the IEPOX-OA factor; whereas summed SOA tracers modeled by assuming $\mathrm{H}^{*}$ of 1 order of magnitude lower yielded an $89 \%$ underestimate of the IEPOX-OA factor $\left(r^{2}=0.62\right)$. The simpleGAMMA model predicts only a subset of IEPOX-derived SOA tracers; thus underestimation of the IEPOX-OA factor is expected.

In addition to the uncertainty in the $\mathrm{H}^{*}$ parameter, several other factors may also contribute to mass disagreement between the tracer estimated by simpleGAMMA and the field data. The box model simulations took locally measured IEPOX and aerosol parameters as inputs, and simulated $12 \mathrm{~h}$ of reactive processing, rather than simulating uptake, reaction, and transport along a trajectory initiating in the valley. The locally measured IEPOX signal is noted above to have interference from ISOPOOH; thus the model outputs likely overestimate the measurements. Examination of IEPOX input variability to simpleGAMMA tracers estimation will be reported in a future study. Additionally, $\mathrm{C}_{5}$-alkene triols, the third largest contributor to the IEPOX-derived SOA tracers, and oligomeric HULIS are not included in the simpleGAMMA model estimation. Neglect of the $\mathrm{C}_{5}$-alkene triols and oligomers as well as yet unknown IEPOX-derived SOA formation pathways by this model could contribute to inaccuracy in estimation of the mass contribution of 2methyltetrols and IEPOX-derived organosulfates to the total amount of IEPOX-derived SOA tracers and reduce the correlation. Finally, oxidative aging of IEPOX SOA tracers is not included in simpleGAMMA at this time due to current lack of availability of kinetic and mechanistic data. Overall, although mass disagreement persists, good correlation between model and field measurements of tracers suggest that the uptake mechanism of IEPOX is consistent with acid-catalyzed mechanism proposed from kinetic (Eddingsaas et al., 2010; Pye et al., 2013) and laboratory studies (Lin et al., 2012; Nguyen et al., 2014).

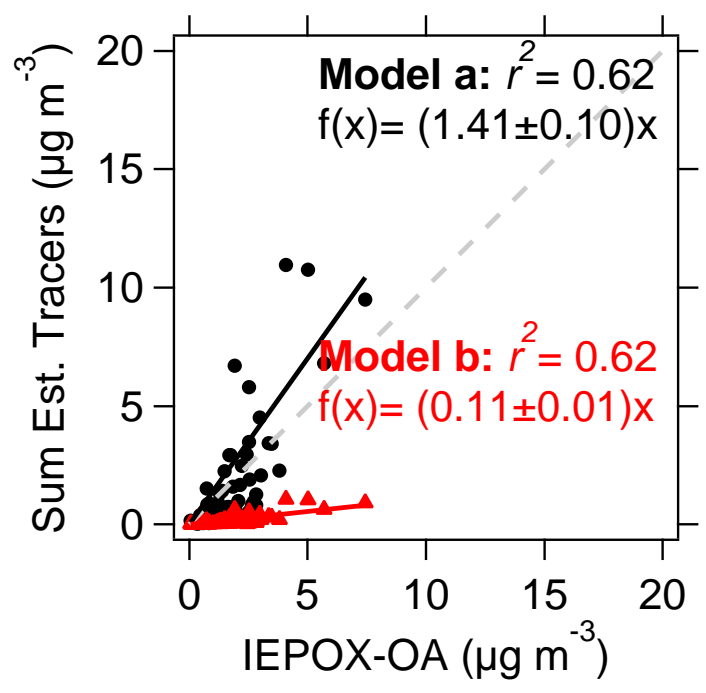

Figure 6. Correlation of summed IEPOX-derived SOA tracers estimated by simpleGAMMA by assuming $\mathrm{H}^{*}$ of $3.0 \times 10^{7}$ (Nguyen et al., 2014) (model a) and $2.7 \times 10^{6}$ (Pye et al., 2013) (model b) and IEPOX-OA factor from PMF analysis.

\section{Conclusions}

Offline chemical analysis of $\mathrm{PM}_{2.5}$ samples collected from LRK, TN, during the 2013 SOAS campaign show a substantial contribution by IEPOX-derived SOA tracers to the total OA mass $(\sim 9 \%$ on average, up to $28 \%)$. A larger contribution $(32 \%)$ to total OA mass is estimated by PMF analysis of the real-time ACSM OA mass spectrometric data. Overall, the importance of IEPOX heterogeneous chemistry in this region is clearly demonstrable. No association was observed between the gas-phase constituents $\mathrm{NO}$ and $\mathrm{NO}_{2}$ and the IEPOX-derived SOA tracers or the IEPOX-OA factor, suggesting that IEPOX-derived SOA is formed upwind or distant from the sampling site. Moderate association between $\mathrm{NO}_{y}$ and MACR-derived SOA tracers was observed, consistent with the proposed involvement of oxidizing nitrogen compounds in MACR-derived SOA formation (Lin et al., 2013b; Nguyen et al., 2015). Particle-phase sulfate is fairly correlated $\left(r^{2}=0.3-0.4\right)$ with both MACR- and IEPOX-derived SOA tracers, and more strongly correlated $\left(r^{2} \sim 0.6\right)$ with the IEPOX-OA factor, overall suggesting that sulfate plays an important role in isoprene SOA formation. However, this association requires further analysis, in light of the proposed formation of IEPOX-derived SOA during transport to LRK from an upwind or down-slope origin. Several explanations may be proposed for the lack of a strong association between isoprene-derived SOA mass and particle acidity: (1) isoprene-derived SOA is not strongly limited by levels of predicted aerosol acidity and LWC even though these are in the favored ranges $(\mathrm{pH}<2)$ to promote sufficient SOA production based on recent laboratory kinetic studies (Gaston et al., 2014; Riedel et al., 2015); thus, other potentially unknown 
controlling factors in this region might need to be considered; (2) no strong correlation exists between SOA mass and local aerosol acidity which estimation is challenging due to changes in particle composition and characteristics during reactive uptake; and (3) several key inter-related variables (LWC, aerosol surface area and aerosol acidity) control SOA yield and thus the correlation of aerosol acidity and SOA yield will be difficult to deconvolute from complex field data until modeling can better constrain these effects. Consistent with the suggestion that IEPOX-derived SOA forms during transport from distant locations, air mass back-trajectory indicated that westerly flow from potential sources of oxidation products where biogenic and anthropogenic emissions can mix, are likely related to episodes of high levels of IEPOXderived SOA measured at LRK. In contrast, when air masses originated mainly from forested and rural areas to the south and southeast of the site, high levels of IEPOX-derived SOA mass were not observed. Good correlation between SOA model outputs and field measurements suggests that gaps remain in our knowledge of isoprene-derived SOA formation. Laboratory studies are needed to reduce the uncertainty in the effective Henry's Law constant, $\mathrm{H}^{*}$, for IEPOX. Additional studies are needed to further quantify the condensedphase mechanism and kinetics of SOA formation via the IEPOX pathway so that it may be represented in more detail in models. Notwithstanding, initial modeling results allow critical insight into how more explicit treatment of the reactions between anthropogenic pollutants and isoprene oxidation products may be incorporated into models of SOA formation. Importantly, by the inclusion of explicit IEPOXand MAE-derived SOA formation pathways in a model, Pye et al. (2013) recently demonstrated that by lowering $\mathrm{SO}_{x}$ emissions in the eastern US by $25 \%$ could lower IEPOXand MAE-derived SOA formation 35 to $40 \%$. Future studies should attempt to improve model predictions of IEPOXderived SOA formation and systematically examine effects of implementing stricter $\mathrm{SO}_{x}$ controls in this region.

\section{The Supplement related to this article is available online at doi:10.5194/acp-15-8871-2015-supplement.}

\footnotetext{
Acknowledgements. This work was funded by the US Environmental Protection Agency (EPA) through grant number 835404. The contents of this publication are solely the responsibility of the authors and do not necessarily represent the official views of the US EPA. Further, the US EPA does not endorse the purchase of any commercial products or services mentioned in the publication. The US EPA through its Office of Research and Development collaborated in the research described here. It has been subjected to Agency review and approved for publication, but may not necessarily reflect official Agency policy. The author would also like to thank the Electric Power Research Institute (EPRI) for their support. This study was supported in part by the National
}

Oceanic and Atmospheric Administration (NOAA) Climate Program Office's AC4 program, award \# NA13OAR4310064. We thank Bill Hicks of the Tennessee Valley Authority (TVA) for his assistance in collecting the collocated monitoring data at the LRK site. S. H. Budisulistiorini was supported by a Fulbright Presidential Fellowship (2010-2013) for attending the University of North Carolina at Chapel Hill and the UNC Graduate School Off-Campus Dissertation Research Fellowship, as well as partial appointment to the Internship/Research Participation Program at the Office of Research and Development, US EPA, administered by the Oak Ridge Institute for Science and Education through an interagency agreement between the US Department of Energy and EPA. M. Neff and E. A. Stone were supported by US EPA Science to Achieve Results (STAR) program grant number 835401. The authors thank Lynn Russell, Timothy Bertram and Christopher Cappa as well as their respective groups for their collaboration during the SOAS campaign at LRK. The authors thank Louisa Emmons for her assistance with forecasts made available during the SOAS campaign. The authors thank John Offenberg for providing access to a Sunset Laboratory OC/EC analysis instrument. The authors also thank Tianqu Cui for his assistance in helping deploy instrumentation from the UNC group, and Wendy Marth and Theran Riedel for their assistance in helping calibrate the acetate CIMS. We would like to thank Annmarie Carlton, Joost deGouw, Jose Jimenez, and Allen Goldstein for helping to organize the SOAS campaign and coordinating communication between ground sites.

Edited by: P. DeCarlo

\section{References}

Aiken, A. C., DeCarlo, P. F., Kroll, J. H., Worsnop, D. R., Huffman, J. A., Docherty, K. S., Ulbrich, I. M., Mohr, C., Kimmel, J. R., Sueper, D., Sun, Y., Zhang, Q., Trimborn, A., Northway, M., Ziemann, P. J., Canagaratna, M. R., Onasch, T. B., Alfarra, M. R., Prevot, A. S. H., Dommen, J., Duplissy, J., Metzger, A., Baltensperger, U., and Jimenez, J. L.: O/C and OM/OC Ratios of Primary, Secondary, and Ambient Organic Aerosols with HighResolution Time-of-Flight Aerosol Mass Spectrometry, Environ. Sci. Technol., 42, 4478-4485, doi:10.1021/es703009q, 2008.

Bates, K. H., Crounse, J. D., St. Clair, J. M., Bennett, N. B., Nguyen, T. B., Seinfeld, J. H., Stoltz, B. M., and Wennberg, P. O.: Gas Phase Production and Loss of Isoprene Epoxydiols, J. Phys. Chem. A, 118, 1237-1246, doi:10.1021/jp4107958, 2014.

Bertram, T. H., Kimmel, J. R., Crisp, T. A., Ryder, O. S., Yatavelli, R. L. N., Thornton, J. A., Cubison, M. J., Gonin, M., and Worsnop, D. R.: A field-deployable, chemical ionization timeof-flight mass spectrometer, Atmos. Meas. Tech., 4, 1471-1479, doi:10.5194/amt-4-1471-2011, 2011.

Birch, M. E. and Cary, R. A.: Elemental carbon-based method for occupational monitoring of particulate diesel exhaust: methodology and exposure issues, Analyst, 121, 1183-1190, doi:10.1039/AN9962101183, 1996.

Budisulistiorini, S. H., Canagaratna, M. R., Croteau, P. L., Marth, W. J., Baumann, K., Edgerton, E. S., Shaw, S. L., Knipping, E. M., Worsnop, D. R., Jayne, J. T., Gold, A., and Surratt, J. D.: Real-Time Continuous Characterization of Secondary Or- 
ganic Aerosol Derived from Isoprene Epoxydiols in Downtown Atlanta, Georgia, Using the Aerodyne Aerosol Chemical Speciation Monitor, Environ. Sci. Technol., 47, 5686-5694, doi:10.1021/es400023n, 2013.

Budisulistiorini, S. H., Canagaratna, M. R., Croteau, P. L., Baumann, K., Edgerton, E. S., Kollman, M. S., Ng, N. L., Verma, V., Shaw, S. L., Knipping, E. M., Worsnop, D. R., Jayne, J. T., Weber, R.J., and Surratt, J. D.: Intercomparison of an Aerosol Chemical Speciation Monitor (ACSM) with ambient fine aerosol measurements in downtown Atlanta, Georgia, Atmos. Meas. Tech., 7, 1929-1941, doi:10.5194/amt-7-1929-2014, 2014.

Carlton, A. G., Bhave, P. V., Napelenok, S. L., Edney, E. O., Sarwar, G., Pinder, R. W., Pouliot, G. A., and Houyoux, M.: Model Representation of Secondary Organic Aerosol in CMAQv4.7, Environ. Sci. Technol., 44, 8553-8560, doi:10.1021/es100636q, 2010.

Chen, Q., Farmer, D. K., Rizzo, L. V., Pauliquevis, T., Kuwata, M., Karl, T. G., Guenther, A., Allan, J. D., Coe, H., Andreae, M. O., Pöschl, U., Jimenez, J. L., Artaxo, P., and Martin, S. T.: Submicron particle mass concentrations and sources in the Amazonian wet season (AMAZE-08), Atmos. Chem. Phys., 15, 3687-3701, doi:10.5194/acp-15-3687-2015, 2015.

Claeys, M., Graham, B., Vas, G., Wang, W., Vermeylen, R., Pashynska, V., Cafmeyer, J., Guyon, P., Andreae, M. O., Artaxo, P., and Maenhaut, W.: Formation of Secondary Organic Aerosols Through Photooxidation of Isoprene, Science, 303, 1173-1176, doi:10.1126/science.1092805, 2004

Cross, E. S., Slowik, J. G., Davidovits, P., Allan, J. D., Worsnop, D. R., Jayne, J. T., Lewis, D. K., Canagaratna, M., and Onasch, T. B.: Laboratory and Ambient Particle Density Determinations using Light Scattering in Conjunction with Aerosol Mass Spectrometry, Aerosol Sci. Tech., 41, 343-359, doi:10.1080/02786820701199736, 2007.

Ding, X., Wang, X., Gao, B., Fu, X., He, Q., Zhao, X., Yu, J., and Zheng, M.: Tracer-based estimation of secondary organic carbon in the Pearl River Delta, south China, J. Geophys. Res., 117, D05313, doi:10.1029/2011JD016596, 2012.

Dockery, D. W., Pope, C. A., Xu, X., Spengler, J. D., Ware, J. H., Fay, M. E., Ferris, B. G., and Speizer, F. E.: An Association between Air Pollution and Mortality in Six U.S. Cities, New. Engl. J. Med., 329, 1753-1759, doi:10.1056/NEJM199312093292401, 1993.

Eddingsaas, N. C., VanderVelde, D. G., and Wennberg, P. O.: Kinetics and Products of the Acid-Catalyzed Ring-Opening of Atmospherically Relevant Butyl Epoxy Alcohols, J. Phys. Chem. A, 114, 8106-8113, doi:10.1021/jp103907c, 2010.

Edney, E. O., Kleindienst, T. E., Jaoui, M., Lewandowski, M., Offenberg, J. H., Wang, W., and Claeys, M.: Formation of 2methyl tetrols and 2-methylglyceric acid in secondary organic aerosol from laboratory irradiated isoprene/ $\mathrm{NO}_{x} / \mathrm{SO}_{2} /$ air mixtures and their detection in ambient $\mathrm{PM}_{2.5}$ samples collected in the eastern United States, Atmos. Environ., 39, 5281-5289, doi:10.1016/j.atmosenv.2005.05.031, 2005.

Foley, K. M., Roselle, S. J., Appel, K. W., Bhave, P. V., Pleim, J. E., Otte, T. L., Mathur, R., Sarwar, G., Young, J. O., Gilliam, R. C., Nolte, C. G., Kelly, J. T., Gilliland, A. B., and Bash, J. O.: Incremental testing of the Community Multiscale Air Quality (CMAQ) modeling system version 4.7, Geosci. Model Dev., 3, 205-226, doi:10.5194/gmd-3-205-2010, 2010.
Fountoukis, C. and Nenes, A.: ISORROPIA II: a computationally efficient thermodynamic equilibrium model for $\mathrm{K}^{+}-\mathrm{Ca}^{2+}$ $\mathrm{Mg}^{2+}-\mathrm{NH}_{+}^{4}-\mathrm{Na}^{+}-\mathrm{SO}_{4}^{2}-\mathrm{NO}_{3}-\mathrm{Cl}-\mathrm{H}_{2} \mathrm{O}$ aerosols, Atmos. Chem. Phys., 7, 4639-4659, doi:10.5194/acp-7-4639-2007, 2007.

Fountoukis, C., Nenes, A., Sullivan, A., Weber, R., Van Reken, T., Fischer, M., Matías, E., Moya, M., Farmer, D., and Cohen, R. C.: Thermodynamic characterization of Mexico City aerosol during MILAGRO 2006, Atmos. Chem. Phys., 9, 2141-2156, doi:10.5194/acp-9-2141-2009, 2009.

Gao, S., Ng, N. L., Keywood, M., Varutbangkul, V., Bahreini, R., Nenes, A., He, J., Yoo, K. Y., Beauchamp, J. L., Hodyss, R. P., Flagan, R. C., and Seinfeld, J. H.: Particle Phase Acidity and Oligomer Formation in Secondary Organic Aerosol, Environ. Sci. Technol., 38, 6582-6589, doi:10.1021/es049125k, 2004.

Gaston, C. J., Riedel, T. P., Zhang, Z., Gold, A., Surratt, J. D., and Thornton, J. A.: Reactive Uptake of an Isoprene-Derived Epoxydiol to Submicron Aerosol Particles, Environ. Sci. Technol., 48, 11178-11186, doi:10.1021/es5034266, 2014.

Gómez-González, Y., Surratt, J. D., Cuyckens, F., Szmigielski, R., Vermeylen, R., Jaoui, M., Lewandowski, M., Offenberg, J. H., Kleindienst, T. E., Edney, E. O., Blockhuys, F., Van Alsenoy, C., Maenhaut, W., and Claeys, M.: Characterization of organosulfates from the photooxidation of isoprene and unsaturated fatty acids in ambient aerosol using liquid chromatography/(-) electrospray ionization mass spectrometry, J. Mass. Spectrom., 43 , 371-382, doi:10.1002/jms.1329, 2008.

Graus, M., Müller, M. and Hansel, A.: High resolution PTRTOF: Quantification and formula confirmation of VOC in real time, J. Am. Soc. Mass Spectr., 21, 1037-1044, doi:10.1016/j.jasms.2010.02.006, 2010.

Guenther, A., Karl, T., Harley, P., Wiedinmyer, C., Palmer, P. I., and Geron, C.: Estimates of global terrestrial isoprene emissions using MEGAN (Model of Emissions of Gases and Aerosols from Nature), Atmos. Chem. Phys., 6, 3181-3210, doi:10.5194/acp-63181-2006, 2006.

Guo, H., Xu, L., Bougiatioti, A., Cerully, K. M., Capps, S. L., Hite Jr., J. R., Carlton, A. G., Lee, S.-H., Bergin, M. H., Ng, N. L., Nenes, A., and Weber, R. J.: Fine-particle water and $\mathrm{pH}$ in the southeastern United States, Atmos. Chem. Phys., 15, 5211-5228, doi:10.5194/acp-15-5211-2015, 2015.

Hallquist, M., Wenger, J. C., Baltensperger, U., Rudich, Y., Simpson, D., Claeys, M., Dommen, J., Donahue, N. M., George, C., Goldstein, A. H., Hamilton, J. F., Herrmann, H., Hoffmann, T., Iinuma, Y., Jang, M., Jenkin, M. E., Jimenez, J. L., Kiendler-Scharr, A., Maenhaut, W., McFiggans, G., Mentel, Th. F., Monod, A., Prévôt, A. S. H., Seinfeld, J. H., Surratt, J. D., Szmigielski, R., and Wildt, J.: The formation, properties and impact of secondary organic aerosol: current and emerging issues, Atmos. Chem. Phys., 9, 5155-5236, doi:10.5194/acp-95155-2009, 2009.

Hayes, P. L., Ortega, A. M., Cubison, M. J., Froyd, K. D., Zhao, Y., Cliff, S. S., Hu, W. W., Toohey, D. W., Flynn, J. H., Lefer, B. L., Grossberg, N., Alvarez, S., Rappenglück, B., Taylor, J. W., Allan, J. D., Holloway, J. S., Gilman, J. B., Kuster, W. C., de Gouw, J. A., Massoli, P., Zhang, X., Liu, J., Weber, R. J., Corrigan, A. L., Russell, L. M., Isaacman, G., Worton, D. R., Kreisberg, N. M., Goldstein, A. H., Thalman, R., Waxman, E. M., Volkamer, R., Lin, Y. H., Surratt, J. D., Kleindienst, T. E., Offenberg, J. H., Dusanter, S., Griffith, S., Stevens, P. S., Brioude, J., Angevine, W. 
M., and Jimenez, J. L.: Organic aerosol composition and sources in Pasadena, California during the 2010 CalNex campaign, J. Geophys. Res., 118, 9233-9233, doi:10.1002/jgrd.50530, 2013.

Hsu, S. O.-I., Ito, K., and Lippmann, M.: Effects of thoracic and fine $\mathrm{PM}$ and their components on heart rate and pulmonary function in COPD patients, J. Expo. Sci. Env. Epid., 21, 464-472, 2011.

IPCC 2013, Climate Change 2013: The Physical Science Basis, Contribution of Working Group I to the Fifth Assessment Report to the Intergovernmental Panel on Climate Change, Cambridge University Press, Cambridge, UK and New York, NY, USA, 2013.

Jacobs, M. I., Darer, A. I., and Elrod, M. J.: Rate Constants and Products of the $\mathrm{OH}$ Reaction with IsopreneDerived Epoxides, Environ. Sci. Technol., 47, 12868-12876, doi:10.1021/es403340g, 2013.

Jang, M., Czoschke, N. M., Lee, S., and Kamens, R. M.: Heterogeneous Atmospheric Aerosol Production by AcidCatalyzed Particle-Phase Reactions, Science, 298, 814-817, doi:10.1126/science.1075798, 2002.

Jimenez, J. L., Canagaratna, M. R., Donahue, N. M., Prevot, A. S. H., Zhang, Q., Kroll, J. H., DeCarlo, P. F., Allan, J. D., Coe, H., Ng, N. L., Aiken, A. C., Docherty, K. S., Ulbrich, I. M., Grieshop, A. P., Robinson, A. L., Duplissy, J., Smith, J. D., Wilson, K. R., Lanz, V. A., Hueglin, C., Sun, Y. L., Tian, J., Laaksonen, A., Raatikainen, T., Rautiainen, J., Vaattovaara, P., Ehn, M., Kulmala, M., Tomlinson, J. M., Collins, D. R., Cubison, M. J., E., Dunlea, J., Huffman, J. A., Onasch, T. B., Alfarra, M. R., Williams, P. I., Bower, K., Kondo, Y., Schneider, J., Drewnick, F., Borrmann, S., Weimer, S., Demerjian, K., Salcedo, D., Cottrell, L., Griffin, R., Takami, A., Miyoshi, T., Hatakeyama, S., Shimono, A., Sun, J. Y., Zhang, Y. M., Dzepina, K., Kimmel, J. R., Sueper, D., Jayne, J. T., Herndon, S. C., Trimborn, A. M., Williams, L. R., Wood, E. C., Middlebrook, A. M., Kolb, C. E., Baltensperger, U., and Worsnop, D. R.: Evolution of Organic Aerosols in the Atmosphere, Science, 326, 1525-1529, doi:10.1126/science.1180353, 2009.

Jordan, A., Haidacher, S., Hanel, G., Hartungen, E., Herbig, J., Märk, L., Schottkowsky, R., Seehauser, H., Sulzer, P., and Märk, T. D.: An online ultra-high sensitivity Proton-transfer-reaction mass-spectrometer combined with switchable reagent ion capability (PTR + SRI-MS), Int. J. Mass. Spectrom., 286, 32-38, doi:10.1016/j.ijms.2009.06.006, 2009a.

Jordan, A., Haidacher, S., Hanel, G., Hartungen, E., Märk, L., Seehauser, H., Schottkowsky, R., Sulzer, P., and Märk, T. D.: A high resolution and high sensitivity proton-transfer-reaction time-offlight mass spectrometer (PTR-TOF-MS), Int. J. Mass. Spectrom., 286, 122-128, doi:10.1016/j.ijms.2009.07.005, 2009b.

Kalberer, M., Paulsen, D., Sax, M., Steinbacher, M., Dommen, J., Prevot, A. S. H., Fisseha, R., Weingartner, E., Frankevich, V., Zenobi, R., and Baltensperger, U.: Identification of Polymers as Major Components of Atmospheric Organic Aerosols, Science, 303, 1659-1662, 2004.

Kamens, R. M., Gery, M. W., Jeffries, H. E., Jackson, M., and Cole, E. I.: Ozone-isoprene reactions: Product formation and aerosol potential, Int. J. Chem. Kinet., 14, 955-975, doi:10.1002/kin.550140902, 1982

Karambelas, A., Pye, H. O. T., Budisulistiorini, S. H., Surratt, J. D., and Pinder, R. W.: Contribution of Isoprene Epoxydiol to Urban Organic Aerosol: Evidence from Modeling and Measurements, Environ. Sci. Technol. Lett., 1, 278-283, doi:10.1021/ez5001353, 2014.

Ke, L., Ding, X., Tanner, R. L., Schauer, J. J., and Zheng, M.: Source contributions to carbonaceous aerosols in the Tennessee Valley Region, Atmos. Environ., 41, 8898-8923, doi:10.1016/j.atmosenv.2007.08.024, 2007.

Kourtchev, I., Copolovici, L., Claeys, M., and Maenhaut, W.: Characterization of Atmospheric Aerosols at a Forested Site in Central Europe, Environ. Sci. Technol., 43, 4665-4671, doi:10.1021/es803055w, 2009.

Kroll, J. H., Ng, N. L., Murphy, S. M., Flagan, R. C., and Seinfeld, J. H.: Secondary Organic Aerosol Formation from Isoprene Photooxidation, Environ. Sci. Technol., 40, 1869-1877, 2006.

Lewis, C. W., Klouda, G. A., and Ellenson, W. D.: Radiocarbon measurement of the biogenic contribution to summertime $\mathrm{PM}_{2.5}$ ambient aerosol in Nashville, TN, Atmos. Environ., 38, 60536061, doi:10.1016/j.atmosenv.2004.06.011, 2004.

Lin, Y., Zhang, Z., Docherty, K. S., Zhang, H., Budisulistiorini, S. H., Rubitschun, C. L., Shaw, S. L., Knipping, E. M., Edgerton, E. S., Kleindienst, T. E., Gold, A., and Surratt, J. D.: Isoprene Epoxydiols as Precursors to Secondary Organic Aerosol Formation: Acid-Catalyzed Reactive Uptake Studies with Authentic Compounds, Environ. Sci. Technol., 46, 250 258, doi:10.1021/es202554c, 2012.

Lin, Y., Budisulistiorini, S. H., Chu, K., Siejack, R. A., Zhang, H., Riva, M., Zhang, Z., Gold, A., Kautzman, K. E., and Surratt, J. D.: Light-Absorbing Oligomer Formation in Secondary Organic Aerosol from Reactive Uptake of Isoprene Epoxydiols, Environ. Sci. Technol., 48, 12012-12021, doi:10.1021/es503142b, 2014.

Lin, Y.-H., Knipping, E. M., Edgerton, E. S., Shaw, S. L., and Surratt, J. D.: Investigating the influences of $\mathrm{SO}_{2}$ and $\mathrm{NH}_{3}$ levels on isoprene-derived secondary organic aerosol formation using conditional sampling approaches, Atmos. Chem. Phys., 13, 84578470, doi:10.5194/acp-13-8457-2013, 2013a.

Lin, Y.-H., Zhang, H., Pye, H. O. T., Zhang, Z., Marth, W. J., Park, S., Arashiro, M., Cui, T., Budisulistiorini, S. H., Sexton, K. G., Vizuete, W., Xie, Y., Luecken, D. J., Piletic, I. R., Edney, E. O., Bartolotti, L. J., Gold, A., and Surratt, J. D.: Epoxide as a precursor to secondary organic aerosol formation from isoprene photooxidation in the presence of nitrogen oxides, P. Natl. Acad. Sci. USA, 110, 6718-6723, doi:10.1073/pnas.1221150110, 2013b.

Liu, Y. J., Herdlinger-Blatt, I., McKinney, K. A., and Martin, S. T.: Production of methyl vinyl ketone and methacrolein via the hydroperoxyl pathway of isoprene oxidation, Atmos. Chem. Phys., 13, 5715-5730, doi:10.5194/acp-13-5715-2013, 2013.

Liu, Y., Kuwata, M., Strick, B. F., Thomson, R. J., Geiger, F. M., McKinney, K., and Martin, S. T.: Uptake of Epoxydiol Isomers Accounts for Half of the Particle-Phase Material Produced from Isoprene Photooxidation via the $\mathrm{HO}_{2}$ pathway, Environ. Sci. Technol., 49, 250-258, doi:10.1021/es5034298, 2014.

Mauderly, J. L. and Chow, J. C.: Health Effects of Organic Aerosols, Inhal. Toxicol., 20, 257-288, doi:10.1080/08958370701866008, 2008.

McNeill, V. F., Woo, J. L., Kim, D. D., Schwier, A. N., Wannell, N. J., Sumner, A. J., and Barakat, J. M.: Aqueous-Phase Secondary Organic Aerosol and Organosulfate Formation in Atmospheric Aerosols: A Modeling Study, Environ. Sci. Technol., 46, 80758081, doi:10.1021/es3002986, 2012. 
Middlebrook, A. M., Bahreini, R., Jimenez, J. L., and Canagaratna, M. R.: Evaluation of Composition-Dependent Collection Efficiencies for the Aerodyne Aerosol Mass Spectrometer using Field Data, Aerosol Sci. Tech., 46, 258-271, doi:10.1080/02786826.2011.620041, 2012.

Nenes, A., Pandis, S. N., and Pilinis, C.: Continued development and testing of a new thermodynamic aerosol module for urban and regional air quality models, Atmos. Environ., 33, 15531560, doi:10.1016/S1352-2310(98)00352-5, 1999.

Ng, N. L., Canagaratna, M. R., Jimenez, J. L., Zhang, Q., Ulbrich, I. M., and Worsnop, D. R.: Real-Time Methods for Estimating Organic Component Mass Concentrations from Aerosol Mass Spectrometer Data, Environ. Sci. Technol., 45, 910-916, doi:10.1021/es102951k, 2011.

Nguyen, T. B., Roach, P. J., Laskin, J., Laskin, A., and Nizkorodov, S. A.: Effect of humidity on the composition of isoprene photooxidation secondary organic aerosol, Atmos. Chem. Phys., 11, 6931-6944, doi:10.5194/acp-11-6931-2011, 2011.

Nguyen, T. B., Coggon, M. M., Bates, K. H., Zhang, X., Schwantes, R. H., Schilling, K. A., Loza, C. L., Flagan, R. C., Wennberg, P. O., and Seinfeld, J. H.: Organic aerosol formation from the reactive uptake of isoprene epoxydiols (IEPOX) onto nonacidified inorganic seeds, Atmos. Chem. Phys., 14, 3497-3510, doi:10.5194/acp-14-3497-2014, 2014

Nguyen, T. B., Bates, K. H., Crounse, J. D., Schwantes, R. H., Zhang, X., Kjaergaard, H., Surratt, J. D., Lin, P., Laskin, A., Seinfeld, J. H., and Wennberg, P. O.: Mechanism of the hydroxyl radical oxidation of methacryloyl peroxynitrate (MPAN) and its pathway toward secondary organic aerosol formation in the atmosphere, Phys. Chem. Chem. Phys., 17, 17914-17926, doi:10.1039/C5CP02001H, 2015.

Odum, J. R., Hoffmann, T., Bowman, F., Collins, D., Flagan, R. C., and Seinfeld, J. H.: Gas/Particle Partitioning and Secondary Organic Aerosol Yields, Environ. Sci. Technol., 30, 2580-2585, doi:10.1021/es950943+, 1996.

Paatero, P. and Tapper, U.: Positive matrix factorization: A non-negative factor model with optimal utilization of error estimates of data values, Environmetrics, 5, 111-126, doi:10.1002/env.3170050203, 1994.

Pandis, S. N., Paulson, S. E., Seinfeld, J. H., and Flagan, R. C.: Aerosol formation in the photooxidation of isoprene and $\beta$-pinene, Atmos. Environ., 25, 997-1008, doi:10.1016/09601686(91)90141-S, 1991.

Pankow, J. F.: An absorption model of gas/particle partitioning of organic compounds in the atmosphere, Atmos. Environ., 28, 185-188, doi:10.1016/1352-2310(94)90093-0, 1994.

Paulot, F., Crounse, J. D., Kjaergaard, H. G., Kürten, A., St. Clair, J. M., Seinfeld, J. H., and Wennberg, P. O.: Unexpected Epoxide Formation in the Gas-Phase Photooxidation of Isoprene, Science, 325, 730-733, doi:10.1126/science.1172910, 2009.

Pye, H. O. T., Pinder, R. W., Piletic, I. R., Xie, Y., Capps, S. L., Lin, Y., Surratt, J. D., Zhang, Z., Gold, A., Luecken, D. J., Hutzell, W. T., Jaoui, M., Offenberg, J. H., Kleindienst, T. E., Lewandowski, M., and Edney, E. O.: Epoxide Pathways Improve Model Predictions of Isoprene Markers and Reveal Key Role of Acidity in Aerosol Formation, Environ. Sci. Technol., 47, 11056-11064, doi:10.1021/es402106h, 2013.

Riedel, T. P., Lin, Y., Budisulistiorini, S. H., Gaston, C. J., Thornton, J. A., Zhang, Z., Vizuete, W., Gold, A., and Surratt, J. D.: Hetero- geneous reactions of isoprene-derived epoxides: reaction probabilities and molar secondary organic aerosol yield estimates, Environ. Sci. Technol. Lett., 2, 38-42, doi:10.1021/ez500406f, 2015.

Robinson, N. H., Hamilton, J. F., Allan, J. D., Langford, B., Oram, D. E., Chen, Q., Docherty, K., Farmer, D. K., Jimenez, J. L., Ward, M. W., Hewitt, C. N., Barley, M. H., Jenkin, M. E., Rickard, A. R., Martin, S. T., McFiggans, G., and Coe, H.: Evidence for a significant proportion of Secondary Organic Aerosol from isoprene above a maritime tropical forest, Atmos. Chem. Phys., 11, 1039-1050, doi:10.5194/acp-11-1039-2011, 2011

Schichtel, B. A., Malm, W. C., Bench, G., Fallon, S., McDade, C. E., Chow, J. C., and Watson, J. G.: Fossil and contemporary fine particulate carbon fractions at 12 rural and urban sites in the United States, J. Geophys. Res., 113, D02311, doi:10.1029/2007JD008605, 2008.

Schindelka, J., Iinuma, Y., Hoffmann, D., and Herrmann, H.: Sulfate radical-initiated formation of isoprene-derived organosulfates in atmospheric aerosols, Faraday Discuss., 165, 237-259, doi:10.1039/C3FD00042G, 2013.

Schwartz, S.: Mass-Transport Considerations Pertinent to Aqueous Phase Reactions of Gases in Liquid-Water Clouds, Chemistry of Multiphase Atmospheric Systems, 6, 415-471, doi:10.1007/9783-642-70627-1_16, 1986.

Slowik, J. G., Brook, J., Chang, R. Y.-W., Evans, G. J., Hayden, K., Jeong, C.-H., Li, S.-M., Liggio, J., Liu, P. S. K., McGuire, M., Mihele, C., Sjostedt, S., Vlasenko, A., and Abbatt, J. P. D.: Photochemical processing of organic aerosol at nearby continental sites: contrast between urban plumes and regional aerosol, Atmos. Chem. Phys., 11, 2991-3006, doi:10.5194/acp-11-29912011, 2011.

Sun, Y., Zhang, Q., Zheng, M., Ding, X., Edgerton, E. S., and Wang, X.: Characterization and Source Apportionment of WaterSoluble Organic Matter in Atmospheric Fine Particles $\left(\mathrm{PM}_{2.5}\right)$ with High-Resolution Aerosol Mass Spectrometry and GC-MS, Environ. Sci. Technol., 45, 4854-4861, doi:10.1021/es200162h, 2011.

Surratt, J. D., Murphy, S. M., Kroll, J. H., Ng, N. L., Hildebrandt, L., Sorooshian, A., Szmigielski, R., Vermeylen, R., Maenhaut, W., Claeys, M., Flagan, R. C., and Seinfeld, J. H.: Chemical Composition of Secondary Organic Aerosol Formed from the Photooxidation of Isoprene, J. Phys. Chem. A, 110, 9665-9690, doi:10.1021/jp061734m, 2006.

Surratt, J. D., Kroll, J. H., Kleindienst, T. E., Edney, E. O., Claeys, M., Sorooshian, A., Ng, N. L., Offenberg, J. H., Lewandowski, M., Jaoui, M., Flagan, R. C., and Seinfeld, J. H.: Evidence for Organosulfates in Secondary Organic Aerosol, Environ. Sci. Technol., 41, 517-527, doi:10.1021/es062081q, 2007a.

Surratt, J. D., Lewandowski, M., Offenberg, J. H., Jaoui, M., Kleindienst, T. E., Edney, E. O., and Seinfeld, J. H.: Effect of Acidity on Secondary Organic Aerosol Formation from Isoprene, Environ. Sci. Technol., 41, 5363-5369, doi:10.1021/es0704176, 2007b.

Surratt, J. D., Gomez-Gonzalez, Y., Chan, A. W. H., Vermeylen, R., Shahgholi, M., Kleindienst, T. E., Edney, E. O., Offenberg, J. H., Lewandowski, M., Jaoui, M., Maenhaut, W., Claeys, M., Flagan, R. C., and Seinfeld, J. H.: Organosulfate Formation in Biogenic Secondary Organic Aerosol, J. Phys. Chem. A, 112, 8345-8378, doi:10.1021/jp802310p, 2008. 
Surratt, J. D., Chan, A. W. H., Eddingsaas, N. C., Chan, M., Loza, C. L., Kwan, A. J., Hersey, S. P., Flagan, R. C., Wennberg, P. O., and Seinfeld, J. H.: Reactive intermediates revealed in secondary organic aerosol formation from isoprene, P. Natl. Acad. Sci. USA, 107, 6640-6645, doi:10.1073/pnas.0911114107, 2010.

Tanner, R. L., Parkhurst, W. J., and McNichol, A. P.: Fossil Sources of Ambient Aerosol Carbon Based on 14C Measurements Special Issue of Aerosol Science and Technology on Findings from the Fine Particulate Matter Supersites Program, Aerosol Sci. Tech., 38, 133-139, doi:10.1080/02786820390229453, 2004.

Tanner, R. L., Bairai, S. T., Olszyna, K. J., Valente, M .L., and Valente, R. J.: Diurnal patterns in $\mathrm{PM}_{2.5}$ mass and composition at a background, complex terrain site, Atmos. Environ., 39, 38653875, doi:10.1016/j.atmosenv.2005.03.014, 2005.

Tanner, R. L., Bairai, S. T., and Mueller, S. F.: Trends in concentrations of atmospheric gaseous and particulate species in rural eastern Tennessee as related to primary emissions reductions, Atmos. Chem. Phys. Discuss., 15, 13211-13262, doi:10.5194/acpd-1513211-2015, 2015.

Tolocka, M. P., Jang, M., Ginter, J. M., Cox, F. J., Kamens, R. M., and Johnston, M. V.: Formation of Oligomers in Secondary Organic Aerosol, Environ. Sci. Technol., 38, 1428-1434, doi:10.1021/es035030r, 2004.

Turpin, B. J. and Lim, H. J.: Species Contributions to $\mathrm{PM}_{2.5}$ Mass Concentrations: Revisiting Common Assumptions for Estimating Organic Mass, Aerosol Sci. Tech., 35, 602-610, doi:10.1080/02786820119445, 2001.

Ulbrich, I. M., Canagaratna, M. R., Zhang, Q., Worsnop, D. R., and Jimenez, J. L.: Interpretation of organic components from Positive Matrix Factorization of aerosol mass spectrometric data, Atmos. Chem. Phys., 9, 2891-2918, doi:10.5194/acp-9-2891-2009, 2009.

Veres, P., Roberts, J. M., Warneke, C., Welsh-Bon, D., Zahniser, M., Herndon, S., Fall, R., and de Gouw, J.: Development of negative-ion proton-transfer chemical-ionization mass spectrometry (NI-PT-CIMS) for the measurement of gas-phase organic acids in the atmosphere, Int. J. Mass Spectrom., 274, 48-55, doi:10.1016/j.ijms.2008.04.032, 2008.

Wang, W., Kourtchev, I., Graham, B., Cafmeyer, J., Maenhaut, W., and Claeys, M.: Characterization of oxygenated derivatives of isoprene related to 2-methyltetrols in Amazonian aerosols using trimethylsilylation and gas chromatography/ion trap mass spectrometry, Rapid Commun. Mass Sp., 19, 13431351, doi:10.1002/rcm.1940, 2005.
Woo, J. L. and McNeill, V. F.: simpleGAMMA v1.0 - a reduced model of secondary organic aerosol formation in the aqueous aerosol phase (aaSOA), Geosci. Model Dev., 8, 1821-1829, doi:10.5194/gmd-8-1821-2015, 2015.

Worton, D. R., Surratt, J. D., LaFranchi, B. W., Chan, A. W. H., Zhao, Y., Weber, R. J., Park, J., Gilman, J. B., de Gouw, J., Park, C., Schade, G., Beaver, M., Clair, J. M. S., Crounse, J., Wennberg, P., Wolfe, G. M., Harrold, S., Thornton, J. A., Farmer, D. K., Docherty, K. S., Cubison, M. J., Jimenez, J., Frossard, A. A., Russell, L. M., Kristensen, K., Glasius, M., Mao, J., Ren, X., Brune, W., Browne, E. C., Pusede, S. E., Cohen, R. C., Seinfeld, J. H., and Goldstein, A. H.: Observational Insights into Aerosol Formation from Isoprene, Environ. Sci. Technol., 47, 11403-11413, doi:10.1021/es4011064, 2013.

Xu, L., Guo, H., Boyd, C. M., Klein, M., Bougiatioti, A., Cerully, K. M., Hite, J. R., Isaacman-VanWertz, G., Kreisberg, N. M., Knote, C., Olson, K., Koss, A., Goldstein, A. H., Hering, S. V., de Gouw, J., Baumann, K., Lee, S., Nenes, A., Weber, R. J., and $\mathrm{Ng}, \mathrm{N}$. L.: Effects of anthropogenic emissions on aerosol formation from isoprene and monoterpenes in the southeastern United States, P. Natl. Acad. Sci. USA, 112, 37-42, doi:10.1073/pnas.1417609112, 2015.

You, Y., Renbaum-Wolff, L., Carreras-Sospedra, M., Hanna, S. J., Hiranuma, N., Kamal, S., Smith, M. L., Zhang, X., Weber, R. J., Shilling, J. E., Dabdub, D., Martin, S. T., and Bertram, A. K.: Images reveal that atmospheric particles can undergo liquidliquid phase separations, P. Natl. Acad. Sci. USA, 109, 1318813193, doi:10.1073/pnas.1206414109, 2012.

Zhang, H., Surratt, J. D., Lin, Y. H., Bapat, J., and Kamens, R. M.: Effect of relative humidity on SOA formation from isoprene/NO photooxidation: enhancement of 2-methylglyceric acid and its corresponding oligoesters under dry conditions, Atmos. Chem. Phys., 11, 6411-6424, doi:10.5194/acp-11-6411-2011, 2011.

Zhang, X., Liu, Z., Hecobian, A., Zheng, M., Frank, N. H., Edgerton, E. S., and Weber, R. J.: Spatial and seasonal variations of fine particle water-soluble organic carbon (WSOC) over the southeastern United States: implications for secondary organic aerosol formation, Atmos. Chem. Phys., 12, 6593-6607, doi:10.5194/acp-12-6593-2012, 2012a.

Zhang, Z., Lin, Y.-H., Zhang, H., Surratt, J. D., Ball, L. M., and Gold, A.: Technical Note: Synthesis of isoprene atmospheric oxidation products: isomeric epoxydiols and the rearrangement products cis- and trans-3-methyl-3,4-dihydroxytetrahydrofuran, Atmos. Chem. Phys., 12, 8529-8535, doi:10.5194/acp-12-85292012, 2012b. 